九州歯会会誌 $40(6): 1297 \sim 1313 ， 1986$.

\title{
沖縄幼児における乳歯列弓の形態学的研究
}

\author{
九州歯科大学口腔衛生学講座（指導：竹原直道教授） \\ (指導：故佐伯榮一教授) \\ 伊波富夫 \\ 昭和 61 年 10 月 23 日受付
}

\section{A Morphological Study on Deciduous Dental Arches of Okinawa Children \\ Tomio Iha}

\author{
Department of Preventive Dentistry (Director: Prof. Tadamichi Takehara) \\ (Director: the late Prof. Eiichi Saeki) \\ Kyushu Dental College, Kitakyushu, Japan
}

\begin{abstract}
Many investigators indicated that there are differences of race and area on human traits. For the present paper, comparative and morphological investigation of the deciduous dentition were made on the plastercasts from 143 Okinawa children ( 82 boys and 61 girls) ranging in age from 3-5 years Kitakyushu children in same age group.
\end{abstract}

The results were as follows:

1. Percentage of normal occlusion of deciduous dentition in Okinawa children was showed $65 \%$ or more in both boys and girls, and it tended higher with an increase in age. In malocclusion, percentage of overbite totaly boys and girls was highest (11.9 $\%$ ), and percentage of edge to edge bite was higher but cross bite was lower in the girls than in the boys.

2. About type of interdental spaces, percentage of mixed type of primate space and developmental space was distinctly higher in the upper dental arch in both boys and girls. But, percentage of closed type as same level as mixed type of primate space and developmental space was higher in the lower dental arch, especially in the girls.

3. About type of terminal plane, percentage of bilateral vertical (straight) type was highest, $56.1 \%$ in the boys and $60.6 \%$ in the girls, then it was higher in order bilateral mesial step type, bilateral distal step type, vertical-mesial step type. No cases of vertical-distal step type and mesial-distal step type was observed.

4. Upper and lower dental arch lengths were not significantly different between boys and girls in OKinawa. It was recognized that lower anterior dental arch lengths were shorter, but upper anterior, upper posterior and lower posterior dental arch lengths were longer in the Okinawa than in the Kitakyushu children in both boys and girls.

5. Upper and lower dental arch breadths were significantly wider in the boys than in the girls. It was recognized that all the items, except lower posterior dental arch 
breadth in the girls, of Okinawa children showed wider levels than Kitakyushu children, especially upper and lower anterior dental arch breadths in the boys and upper anterior dental arch breadth in the girls.

6. All the dental arch indices were not significant difference between boys and girls in Okinawa. It was recognized that upper and lower anterior-posterior dental arch breadth indices were significantly higher in the Okinawa than in the Kitakyushu chiIdren in both boys and girls, but in the boys, lower anterior-posterior dental arch length index and lower anterior arch index were significantly lower in the Okinawa than in the Kitakyushu children.

Key words : Okinawa children/Occluding condition/Interdental spaces/ Terminal plane/Dental arch length/Dental arch breadth

緒

\section{言}

口腔の諸形質の特徵を明らかにすることは, 人類学的 意義もさることながら，臨床の面においても充分に価值 あるととと考えられる。特に，乳㐘列局関しては，蒾 列不正や艾合異常, 顎の成長発育に伴う歯間空隙の形態 や菌列弓長, 幅の年齢的変移等, 永久歯列弓への変換を 前にして，予防矯正学的問題も大なるものがある。従来 より, 当教空では, 茵列弓や口蓋の形質人類学的調査を 行なって扔り，その結果，同人種間でも民族差があり， また，同民族間でも地域差，性差のあることを報告して きたが1-8)，乳雨列局に関する研究は北九州市の幼児を 刘象とした北島 (1974) ${ }^{9 \prime}$ ， 精神発達遅滞児を対象とし た安藤 (1984)101があるのみである.

そてで, 著者は, 沖縄本島の $3 \sim 5$ 歳児男女について, 乳㐘列马の諸形質を調查し, 北九州幼児やいわゆる内地 での報告值との比較，また，沖縄成人女性を報告した教 室河野 $\left.(1982)^{6}\right)^{\prime}$ の永久雪列の特徵と対比させ, 與味あ る知見を得たので報告する。

\section{研 究 方 法}

\section{I . 研究資料}

研究に用いた対象は, 沖䋥県那苚市内の保充園呪のう $ち$, Hellman dental age II A, すなわち, 乳歯列咬合 が完成し第 1 大曰歯萌出以前の乳歯列を有し, 敨蝕もし くは久損菌を持たない $3 \sim 5$ 歳の男 82 名, 女61名, 計 143名である (表 1 ). なお, 歯列弓の計測に関しては, コントロールとして, 北九州市内の $3 \sim 5$ 歳の幼児, 男 40名，女28名についても行なった。資料作成にあたって は，アルギン酸印象材 (ハィ・テクニコール， GC 社製) 在, 粉末 $21 \mathrm{~g}$ に対し, 約 $20^{\circ} \mathrm{C}$ に調節した水 $47 \mathrm{cc}$ の割
表 1 調查人員

\begin{tabular}{ll|l|l}
\hline & & 男 & 女 \\
\hline 3 & 歳 & 16 & 13 \\
4 & 歳 & 41 & 35 \\
5 & 歳 & 25 & 13 \\
\hline & 䚺 & 82 & 61 \\
\hline
\end{tabular}

合で練和, 印象採得後, 直ちに石高 $100 \mathrm{~g}$ 亿対し水 $24 \mathrm{cc}$ で練和した硬石壕（プラストーン，GC 社製）を注入し， 観察および計測用上下顎石膏模型とした。

\section{II. 項目および方法}

観察および計測項目は，小野ら $(1960)^{11)}$ ，望月（19 65) ${ }^{12)}$, 一色ら $(1970)^{13)}$, 兼松 (1973 ${ }^{14)}$ らの方法に 従い，計測には三豊製 1 級)ギス（1/20 mm 副尺付）を 用い，上下顎石高模型上で行なった。

A. 乳米列咬合状態

乳䨑列の晈合状態は，被蓋関係が正常，Overbite が 下顎乳中切歯冠 $1 / 2$ 以内, Overjet は上下歯冠に扔いて咬 合接触しているものを正常咬合とし, 不正咬合は観相学 的分類によって切端咬合, 上顎前突, 過蓋咬合, 反対咬 合, 交叉咬合, 開口のそれぞれ出現頻度を調べた。なお, 不正咬合は捻転，転位など個々の歯牙の不正を入れず， 咬合関係の不正についてのみ取扱った（表 2 ）。

B . 乳歯列の柬間空隙型分類

Primate space (霊長空隙, 以下 PS と略す) は, 上 顎では乳犬苗の近心，下顎では乳犬雷の遠心とし，Developmental space (成長空腺, 以下 DS と略す) は, PS 以外の成長によって生じたと思われる空陌とした。 
表 2 乳歯列开咬合状態判定基準

正常咬合 1 . 被蓋関係が正常であるもの

2. over bite が下㖽乳中切歯歯冠 $1 / 2$ ? 越えないもので，over jet は上下柬 冠において咬合接触しているもの

3. caries が咬合面にあっても, 柬冠形 態をそこなわないもの

上影前突 over jet が大きく上下顎前苗が咬合接 触していないもの

反対晈合 前霜部が 2 㐘以上逆被蓋しているもの

過蓋咬合 over bite が下額乳中切歯歯冠 $2 / 3$ 以上で 咬合するもの

開 咬 マイナスの over bite を示し, 前歯部 で咬合しないもの

切端咬合 上・下乳前曾が切端で咬合するもの

交叉咬合 上・下顎歯列弓が 1 点で交叉咬合するも D

なお，両者を兼ねそなえる場合，程度の強い方をそ の人の咬合状態とした。

上下䕱別に, 空隙型として PS のみ, DSのみ, PS と DS の複合型，および閉鎖型（Close）に分類した。

C. Terminal plane 型別分類

Terminal plane は, 上下顎第 2 乳罒菌遠心面を連为 た仮想垂線を引き,その状態から, Vertical type, Mesial step type, Distal step type の 3 型について, 両側垂直型（VV 型），両側下顎近心型（MM 型），両側 下顎遠心型 (DD 型)，片側垂直型 (VM または VD 型)， および片側近心片側遠心型（MD 型）に分類した。

D. 粜列当長

上下顎それぞれ, 左右側乳犬蒾, 第 2 乳田歯の同名萰 牙部の柬列弓幅計測点を通る直線と, 左右側乳中切㐘唇 面に接する面との距離を計測し，前者を前雪列弓長，後 者を後茵列弓長とした（図1）.

E. 崡列弓幅

上下顎それぞれ, 左右側乳犬茵尖頭頂, 第 2 乳臼粜近 心煩側分界溝部を計測点とし, 左右側乳犬歯尖頭頂間の 距離を前歯列弓幅, 左右側第 2 乳曰歯近心煩側分界溝間 の距離を後歯列弓幅とした（図 1 ）。

F . 柬列可指数

上下顎それぞれ以下゙の式により算出した。

1. 前後料列局長指数

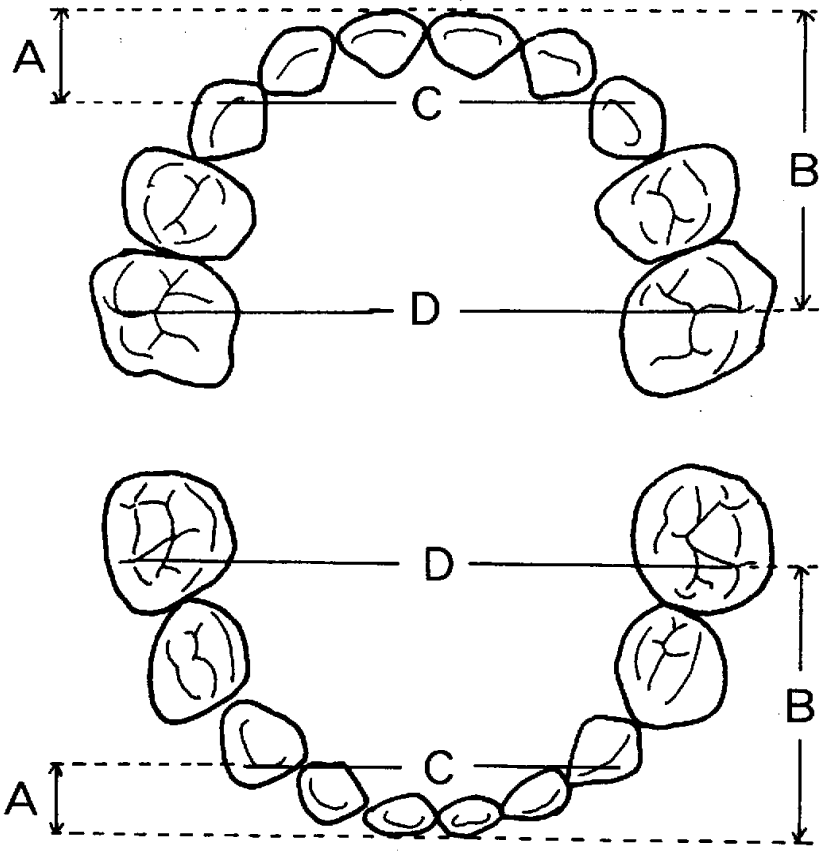
A：前歯列弓長
B：後菌列弓長
C：前菓列弓幅
$\mathrm{D} ：$ 後歯列弓幅

図 1 粜列弓計測部位

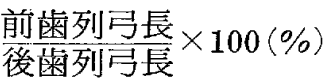

2 . 前後雬列引幅指数

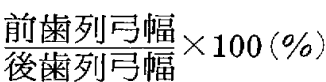

3. 前粜列局指数

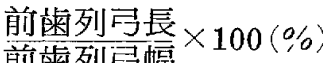

4 . 後粜列引指数

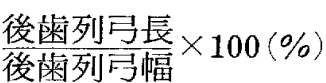

III. 計測值の取扱い

柬列弓長, 歯列弓幅などについては, 計測項目ごとに 通法に従ってそれぞれ平均值 $(\overline{\mathbf{X}})$ ，標準偏差 (s.d.) を求めた。 また，有意性の判定には，あらかじめF検定 で分散を吟味した後, $\mathrm{t}$ 検定あるいは Cochran-Cox の近似法を行ない，有意水準 $1 \%$ もしくは $5 \%$ にて差の 有意性を検討した。

\section{成 績}

I . 乳㐘列咬合状態

乳歯列の咬合状態は, 男女とも正常咬合者が $65 \%$ 強 と，被検児の約 3 分の 2 を占めていた．年歯別にみる 
表 3

咬合状態の出現頻度

\begin{tabular}{|c|c|c|c|c|c|c|c|c|c|}
\hline \multirow{2}{*}{ 咬合状態 } & \multicolumn{4}{|c|}{ 男 } & \multicolumn{4}{|c|}{ 女 } & \multirow{2}{*}{ 全 } \\
\hline & 歳 & 歳 & 5 歳 & 計 & 歳 & 4 歳 & 5 歳 & 計 & \\
\hline 正常咬合 & $\begin{array}{r}43.8 \% \\
(7)\end{array}$ & $\begin{array}{r}63.4 \% \\
(26)\end{array}$ & $\begin{array}{r}88.0 \% \\
(22)\end{array}$ & $\begin{array}{r}67.1 \% \\
(55)\end{array}$ & $\begin{array}{r}53.8 \% \\
(7)\end{array}$ & $\begin{array}{r}65.7 \% \\
(23)\end{array}$ & $\begin{array}{r}76.9 \% \\
(10)\end{array}$ & $\begin{array}{r}65.6 \% \\
(40)\end{array}$ & $\begin{array}{r}66.4 \% \\
(95)\end{array}$ \\
\hline 切端咬合 & $\begin{array}{c}0.0 \% \\
(0)\end{array}$ & $\begin{array}{c}9.8 \% \\
(4)\end{array}$ & $\begin{array}{c}4.0 \% \\
\left(\begin{array}{c}1 \\
\text { (1) }\end{array}\right.\end{array}$ & $\begin{array}{r}6.1 \% \\
(5)\end{array}$ & $\begin{array}{c}7.7 \% \\
(1)\end{array}$ & $\begin{array}{r}14.3 \% \\
(5)\end{array}$ & $\begin{array}{c}7.7 \% \\
(1)\end{array}$ & $\begin{array}{r}11.5 \% \\
(7)\end{array}$ & $\begin{array}{c}8.4 \% \\
(12)\end{array}$ \\
\hline 上顎 前 突 & $\begin{array}{r}12.5 \% \\
(2)\end{array}$ & $\begin{array}{c}2.4 \% \\
(1)\end{array}$ & $\begin{array}{r}4.0 \% \\
(1)\end{array}$ & $\begin{array}{c}4.9 \% \\
(4)\end{array}$ & $\begin{array}{r}15.4 \% \\
(2)\end{array}$ & $\begin{array}{c}0.0 \% \\
(0)\end{array}$ & $\begin{array}{r}0.0 \% \\
\left(\begin{array}{c}0 \\
0\end{array}\right)\end{array}$ & $\begin{array}{c}3.3 \% \\
(2)\end{array}$ & $\begin{array}{c}4.2 \% \\
(6)\end{array}$ \\
\hline 過蓋咬合 & $\begin{array}{r}18.8 \% \\
(3)\end{array}$ & $\begin{array}{r}14.6 \% \\
6 \\
6\end{array}$ & $\begin{array}{c}4.0 \% \\
(1)\end{array}$ & $\begin{array}{r}12.2 \% \\
(10)\end{array}$ & $\begin{array}{r}15.4 \% \\
(2)\end{array}$ & $\begin{array}{r}11.4 \% \\
(4)\end{array}$ & $\begin{array}{c}7.7 \% \\
(1)\end{array}$ & $\begin{array}{r}11.5 \% \\
(7)\end{array}$ & $\begin{array}{r}11.9 \% \\
(17)\end{array}$ \\
\hline 反対咬合 & $\begin{array}{c}6.3 \% \\
(1)\end{array}$ & $\begin{array}{r}0.0 \% \\
(0)\end{array}$ & $\begin{array}{r}0.0 \% \\
(0)\end{array}$ & $\begin{array}{c}1.2 \% \\
\left(\begin{array}{c}1 \\
1\end{array}\right)\end{array}$ & $\begin{array}{r}0.0 \% \\
(0)\end{array}$ & $\begin{array}{c}0.0 \% \\
(0)\end{array}$ & $\begin{array}{c}0.0 \% \\
\left(\begin{array}{c}0 \\
0\end{array}\right)\end{array}$ & $\begin{array}{c}0.0 \% \\
(0)\end{array}$ & $\begin{array}{r}0.7 \% \\
(1)\end{array}$ \\
\hline 交文咬合 & $\begin{array}{r}18.8 \% \\
(3)\end{array}$ & $\begin{array}{c}7.3 \% \\
(3)\end{array}$ & $\begin{array}{c}0.0 \% \\
(0)\end{array}$ & $\begin{array}{r}7.3 \% \\
(6)\end{array}$ & $\begin{array}{c}0.0 \% \\
(0)\end{array}$ & $\begin{array}{r}8.6 \% \\
(3)\end{array}$ & $\begin{array}{c}0.0 \% \\
(0)\end{array}$ & $\begin{array}{r}4.9 \% \\
(3)\end{array}$ & $\begin{array}{c}6.3 \% \\
(9)\end{array}$ \\
\hline 開 & $\begin{array}{c}0.0 \% \\
(0)\end{array}$ & $\begin{array}{r}2.4 \% \\
(1)\end{array}$ & $\begin{array}{c}0.0 \% \\
(0)\end{array}$ & $\begin{array}{c}1.2 \% \\
(1)\end{array}$ & $\begin{array}{r}7.7 \% \\
(1)\end{array}$ & $\begin{array}{r}0.0 \% \\
\left(\begin{array}{c}0 \\
0\end{array}\right)\end{array}$ & $\begin{array}{c}7.7 \% \\
\left(\begin{array}{c}1 \\
1\end{array}\right)\end{array}$ & $\begin{array}{c}3.3 \% \\
(2)\end{array}$ & $\begin{array}{c}2.1 \% \\
(3)\end{array}$ \\
\hline
\end{tabular}

()$=$ 人数

と, 男女とも高年齢児ほど高い割合を示し, 男では 5 歳 児 $(88.0 \%)$ は 3 歳児 $(43.8 \%)$ の約 2 倍, 女では 5 歳 児 $(76.9 \%)$ は 3 歳児 $(53.8 \%)$ の約 1.4 倍高率であっ た．正常咬合の割合は各年齢とも男女間にあまり差はな かった，不正咬合の出現頻度を全体 (男女計)でみると， 過蓋咬合が $11.9 \%$ と最も高く，次いで，切端咬合 $(8.4$ $\%)$, 交叉咬合 $(6.3 \%)$, 上領前突 $(4.2 \%)$, 開口 $(2.1$ $\%)$, 反対咬合 $(0.7 \%)$ の順であった，男女別にみると， 切端咬合は女児の方が高く, 交叉咬合は男の方が高い傾 向であった。(表 3 ).

II . 蒾間空隙の型別出現頻度

閉鎖型は，上䋶では男 $6.1 \%$,女 $23.0 \%$ ，下顎では男 $30.5 \%$, 女 $52.5 \%$ で，女が男より高い傾向が認められ た. 空隙型では PS+DS が最も高く, 上顽では男65.9 $\%$ ，女54.0\%，下顝では男 $37.8 \% ， 女 21.3 \%$ を認めた。 下顎女で DS のみが $21.3 \%$ と，PS のみ $(4.9 \%)$ 上り高 かった以外は，上下顎とも男女とも PS のみが DS の みより高い傾向であった（表 $4 ， 5$ ).

\section{Terminal plane の型別出現頻度}

Terminal plane の型別では, 男女とも VV 型が最 も高く，男 $56.1 \%$ ，女60.6\%であった．次いで，MM型 が男 $35.4 \%$, 女 $29.5 \%$ と高く, DD 型, VM 型は僅かで あった，なお，VD型，MD型は男女とも 1 名も認めら れなかった（表 6 ）。

IV . 雨列廌
上顎前崡列弓長は $3 \sim 5$ 歳全体でみると, 男 $8.73 \pm$ $1.38 \mathrm{~mm}$, 女 $8.54 \pm 1.07 \mathrm{~mm}$, 上效後歯列弓長は, 男 $23.36 \pm 1.76 \mathrm{~mm}$, 女 $22.99 \pm 1.73 \mathrm{~mm}$, 下顎前歯列弓長 は, 男 $5.38 \pm 1.19 \mathrm{~mm}$, 女 $5.11 \pm 1.51 \mathrm{~mm}$, 下靧後菌列 弓長は, 男 $20.09 \pm 1.85 \mathrm{~mm}$, 女 $19.67 \pm 1.95 \mathrm{~mm}$ であ り，いずれの項目も男が女より長い傾向が㸾められた が, 有意差は示さなかった。また, 年㱓別にみても, 各 項目とも有意な性差は認められなかった，歯列马長を年 略間で比較すると, 下顎前歯列弓長では, 男女とも， 3 歳児より 5 歳児が, また， 4 歳児より 5 歳児が有意（p <0.01，0.05）に長い結果が認められたが, 他の部位で は， 5 歳児が $3 ， 4$ 歳児に比してやや長い傾向にあるも のの，著差は認められなかった（表 7 ）。

沖縄幼児の菌列弓長を北九州幼児と比較すると, 男女 とも，下顎前歯列马長では沖綶幼坚が北九州幼児より短 い傾向にあり，特に男では有意差 $(\mathbf{p}<0.01)$ が認められ た.しかしながら, 上顎前および後霜列弓長, 下顎後歯 列高長では，逆に，男女とも沛縄幼児が北九州幼児より 長い傾向にあり, 特に, 女の上顎前わよび後歯列弓長, 男の下顎後柬列弓長に有意差 $(\mathbf{p}<0.01,0.05)$ が認め られた（表 8 , 図 2,3 ).

\section{$\mathrm{V}$ ．蒾列弓幅}

上顎雨列弓幅は， $3 \sim 5$ 歳全体でみると, 女 $30.71 士$ $1.77 \mathrm{~mm}$ に対し男が $31.78 \pm 1.92 \mathrm{~mm}$ と有意 $(\mathrm{p}<0.01)$ に広く，また， 5 歳児でも女 $30.21 \pm 2.55 \mathrm{~mm}$ に対し男 
表 4

匊間空隙の型別出現頻度（上顎）

\begin{tabular}{|c|c|c|c|c|c|c|c|c|c|}
\hline \multirow{2}{*}{ 歯 間 空 隙 } & \multicolumn{4}{|c|}{ 男 } & \multicolumn{4}{|c|}{ 女 } & \multirow{2}{*}{ 全 体 } \\
\hline & 3 墄 & 4 歳 & 5 歳 & 計 & 3 歳 & 4 歳 & 5 歳 & 計 & \\
\hline PS のみ & $\begin{array}{r}37.5 \% \\
(6)\end{array}$ & $\begin{array}{c}29.3 \% \\
(12)\end{array}$ & $\begin{array}{c}16.0 \% \\
\left(\begin{array}{c}4 \\
4\end{array}\right)\end{array}$ & $\begin{array}{r}26.8 \% \\
(22)\end{array}$ & $\begin{array}{c}23.1 \% \\
(3)\end{array}$ & $\begin{array}{c}25.7 \% \\
(9)\end{array}$ & $\begin{array}{c}15.4 \% \\
(2)\end{array}$ & $\begin{array}{c}23.0 \% \\
(14)\end{array}$ & $\begin{array}{c}25.2 \% \\
(36)\end{array}$ \\
\hline $\mathbf{P S}+\mathrm{DS}$ & $\begin{array}{r}62.5 \% \\
(10)\end{array}$ & $\begin{array}{c}58.5 \% \\
(24)\end{array}$ & $\begin{array}{r}80.0 \% \\
(20)\end{array}$ & $\begin{array}{c}65.9 \% \\
(54)\end{array}$ & $\begin{array}{c}46.2 \% \\
(6)\end{array}$ & $\begin{array}{r}51.4 \% \\
(18)\end{array}$ & $\begin{array}{r}69.2 \% \\
(9)\end{array}$ & $\begin{array}{r}54.0 \% \\
(33)\end{array}$ & $\begin{array}{c}60.8 \% \\
(87)\end{array}$ \\
\hline DS のみ & $\begin{array}{r}0.0 \% \\
(0)\end{array}$ & $\begin{array}{r}2.4 \% \\
(1)\end{array}$ & $\begin{array}{r}0.0 \% \\
(0)\end{array}$ & $\begin{array}{c}1.2 \% \\
\left(\begin{array}{c}1\end{array}\right)\end{array}$ & $\begin{array}{c}0.0 \% \\
\left(\begin{array}{c}0\end{array}\right)\end{array}$ & $\begin{array}{c}0.0 \% \\
\left(\begin{array}{c}0 \\
0\end{array}\right)\end{array}$ & $\begin{array}{r}0.0 \% \\
(0)\end{array}$ & $\begin{array}{r}0.0 \% \\
(0)\end{array}$ & $\begin{array}{c}0.7 \% \\
(1)\end{array}$ \\
\hline Close & $\begin{array}{r}0.0 \% \\
(0)\end{array}$ & $\begin{array}{r}9.8 \% \\
(4)\end{array}$ & $\begin{array}{c}4.0 \% \\
\left(\begin{array}{c}1\end{array}\right)\end{array}$ & $\begin{array}{c}6.1 \% \\
(5)\end{array}$ & $\begin{array}{c}30.8 \% \\
(4)\end{array}$ & $\begin{array}{c}22.9 \% \\
(8)\end{array}$ & $\begin{array}{r}15.4 \% \\
(2)\end{array}$ & $\begin{array}{r}23.0 \% \\
(14)\end{array}$ & $\begin{array}{c}13.3 \% \\
(19)\end{array}$ \\
\hline
\end{tabular}

PS : 霊長空陌 DS : 成長空院

\section{Close：閉鎖型}

$(\quad)$ 人数

表 5 茵問空陌の型別出現頻度（下蕷）

\begin{tabular}{|c|c|c|c|c|c|c|c|c|c|}
\hline \multirow{2}{*}{ 㐘間 空 隙 } & \multicolumn{4}{|c|}{ 男 } & \multicolumn{4}{|c|}{ 女 } & \multirow{2}{*}{ 全 体 } \\
\hline & 3 歳 & 4 歳 & 5 歳 & 計 & 3. 歳 & 4 歳 & 5 歳 & 話十 & \\
\hline PS のみ & $\begin{array}{r}43.8 \% \\
(7)\end{array}$ & $\begin{array}{r}22.0 \% \\
(9)\end{array}$ & $\begin{array}{r}16.0 \% \\
(4)\end{array}$ & $\begin{array}{r}24.4 \% \\
(20)\end{array}$ & $\begin{array}{r}0.0 \% \\
(0)\end{array}$ & $\begin{array}{r}2.9 \% \\
(1)\end{array}$ & $\begin{array}{r}15.4 \% \\
(2)\end{array}$ & $\begin{array}{r}4.9 \% \\
(3)\end{array}$ & $\begin{array}{c}16.1 \% \\
(23)\end{array}$ \\
\hline $\mathrm{PS}+\mathrm{DS}$ & $\begin{array}{r}25.0 \% \\
(4)\end{array}$ & $\begin{array}{r}43.9 \% \\
(18)\end{array}$ & $\begin{array}{c}36.0 \% \\
(9)\end{array}$ & $\begin{array}{r}37.8 \% \\
(31)\end{array}$ & $\begin{array}{r}7.7 \% \\
(1)\end{array}$ & $\begin{array}{r}22.9 \% \\
(8)\end{array}$ & $\begin{array}{r}30.8 \% \\
(4)\end{array}$ & $\begin{array}{r}21.3 \% \\
(13)\end{array}$ & $\begin{array}{r}30.8 \% \\
(44)\end{array}$ \\
\hline DS のみ & $\begin{array}{r}0.0 \% \\
(0)\end{array}$ & $\begin{array}{r}4.9 \% \\
(2)\end{array}$ & $\begin{array}{r}16.0 \% \\
(4)\end{array}$ & $\begin{array}{c}7.3 \% \\
(6)\end{array}$ & $\begin{array}{r}15.4 \% \\
(2)\end{array}$ & $\begin{array}{r}17.1 \% \\
(6)\end{array}$ & $\begin{array}{r}38.5 \% \\
(5)\end{array}$ & $\begin{array}{r}21.3 \% \\
(13)\end{array}$ & $\begin{array}{r}13.3 \% \\
(19)\end{array}$ \\
\hline Close & $\begin{array}{r}31.3 \% \\
(5)\end{array}$ & $\begin{array}{r}29.3 \% \\
(12)\end{array}$ & $\begin{array}{r}32.0 \% \\
(8)\end{array}$ & $\begin{array}{r}30.5 \% \\
(25)\end{array}$ & $\begin{array}{c}76.9 \% \\
(10)\end{array}$ & $\begin{array}{c}57.1 \% \\
(20)\end{array}$ & $\begin{array}{r}15.4 \% \\
(2)\end{array}$ & $\begin{array}{c}52.5 \% \\
(32)\end{array}$ & $\begin{array}{c}39.8 \% \\
(57)\end{array}$ \\
\hline
\end{tabular}

PS : 麗長空隙 DS : 成長空陌 Close : 閉鎖型

( ) =人数

表 6 Terminal plane $の$ 型別出現頻度

\begin{tabular}{|c|c|c|c|c|c|c|c|c|c|c|}
\hline \multirow{2}{*}{ 型 } & \multirow{2}{*}{ 別 } & \multicolumn{4}{|c|}{ 男 } & \multicolumn{4}{|c|}{ 女 } & \multirow{2}{*}{ 全 体 } \\
\hline & & 3 歳 & 4 歳 & 5 葴 & 計 & 3 歳 & 4 歳 & 5 歳 & 計 & \\
\hline VV & 型 & $\begin{array}{r}43.8 \% \\
(7)\end{array}$ & $\begin{array}{r}61.0 \% \\
(25)\end{array}$ & $\begin{array}{r}56.0 \% \\
(14)\end{array}$ & $\begin{array}{c}56.1 \% \\
(46)\end{array}$ & $\begin{array}{r}69.2 \% \\
(9)\end{array}$ & $\begin{array}{r}62.9 \% \\
(22)\end{array}$ & $\begin{array}{r}46.2 \% \\
(6)\end{array}$ & $\begin{array}{c}60.6 \% \\
(37)\end{array}$ & $\begin{array}{c}58.0 \% \\
(83)\end{array}$ \\
\hline MM & 型 & $\begin{array}{r}37.5 \% \\
(6)\end{array}$ & $\begin{array}{r}31.7 \% \\
(13)\end{array}$ & $\begin{array}{c}40.0 \% \\
(10)\end{array}$ & $\begin{array}{r}35.4 \% \\
(29)\end{array}$ & $\begin{array}{c}30.8 \% \\
(4)\end{array}$ & $\begin{array}{c}31.4 \% \\
(11)\end{array}$ & $\begin{array}{c}23.1 \% \\
(3)\end{array}$ & $\begin{array}{c}29.5 \% \\
(18)\end{array}$ & $\begin{array}{c}32.9 \% \\
(47)\end{array}$ \\
\hline DD & 型 & $\begin{array}{r}0.0 \% \\
(0)\end{array}$ & $\begin{array}{r}4.9 \% \\
(2)\end{array}$ & $\begin{array}{r}0.0 \% \\
(0)\end{array}$ & $\begin{array}{r}2.4 \% \\
(2)\end{array}$ & $\begin{array}{r}0.0 \% \\
(0)\end{array}$ & $\begin{array}{r}2.9 \% \\
(1)\end{array}$ & $\begin{array}{r}23.1 \% \\
(3)\end{array}$ & $\begin{array}{c}6.6 \% \\
(4)\end{array}$ & $\begin{array}{r}4.2 \% \\
(6)\end{array}$ \\
\hline VM & 型 & $\begin{array}{c}18.8 \% \\
(3)\end{array}$ & $\begin{array}{r}2.4 \% \\
(1)\end{array}$ & $\begin{array}{c}4.0 \% \\
\left(\begin{array}{c}1\end{array}\right)\end{array}$ & $\begin{array}{c}6.1 \% \\
(5)\end{array}$ & $\begin{array}{r}0.0 \% \\
(0)\end{array}$ & $\begin{array}{c}2.9 \% \\
(1)\end{array}$ & $\begin{array}{c}7.7 \% \\
(1)\end{array}$ & $\begin{array}{c}3.3 \% \\
(2)\end{array}$ & $\begin{array}{c}4.9 \% \\
(7)\end{array}$ \\
\hline VD & 型 & $\begin{array}{r}0.0 \% \\
(0)\end{array}$ & $\begin{array}{r}0.0 \% \\
(0)\end{array}$ & $\begin{array}{r}0.0 \% \\
(0)\end{array}$ & $\begin{array}{r}0.0 \% \\
\left(\begin{array}{c}0\end{array}\right)\end{array}$ & $\begin{array}{r}0.0 \% \\
(0)\end{array}$ & $\begin{array}{c}0.0 \% \\
(0)\end{array}$ & $\begin{array}{c}0.0 \% \\
(0)\end{array}$ & $\begin{array}{c}0.0 \% \\
(0)\end{array}$ & $\begin{array}{r}0.0 \% \\
(0)\end{array}$ \\
\hline MD & 型 & $\begin{array}{r}0.0 \% \\
(0)\end{array}$ & $\begin{array}{r}0.0 \% \\
(0)\end{array}$ & $\begin{array}{r}0.0 \% \\
\left(\begin{array}{c}0\end{array}\right)\end{array}$ & $\begin{array}{c}0.0 \% \\
(0)\end{array}$ & $\begin{array}{c}0.0 \% \\
(0)\end{array}$ & $\begin{array}{c}0.0 \% \\
(0)\end{array}$ & $\begin{array}{r}0.0 \% \\
(0)\end{array}$ & $\begin{array}{c}0.0 \% \\
(0)\end{array}$ & $\begin{array}{r}0.0 \% \\
(0)\end{array}$ \\
\hline
\end{tabular}


表 7 歯 列 弓 長

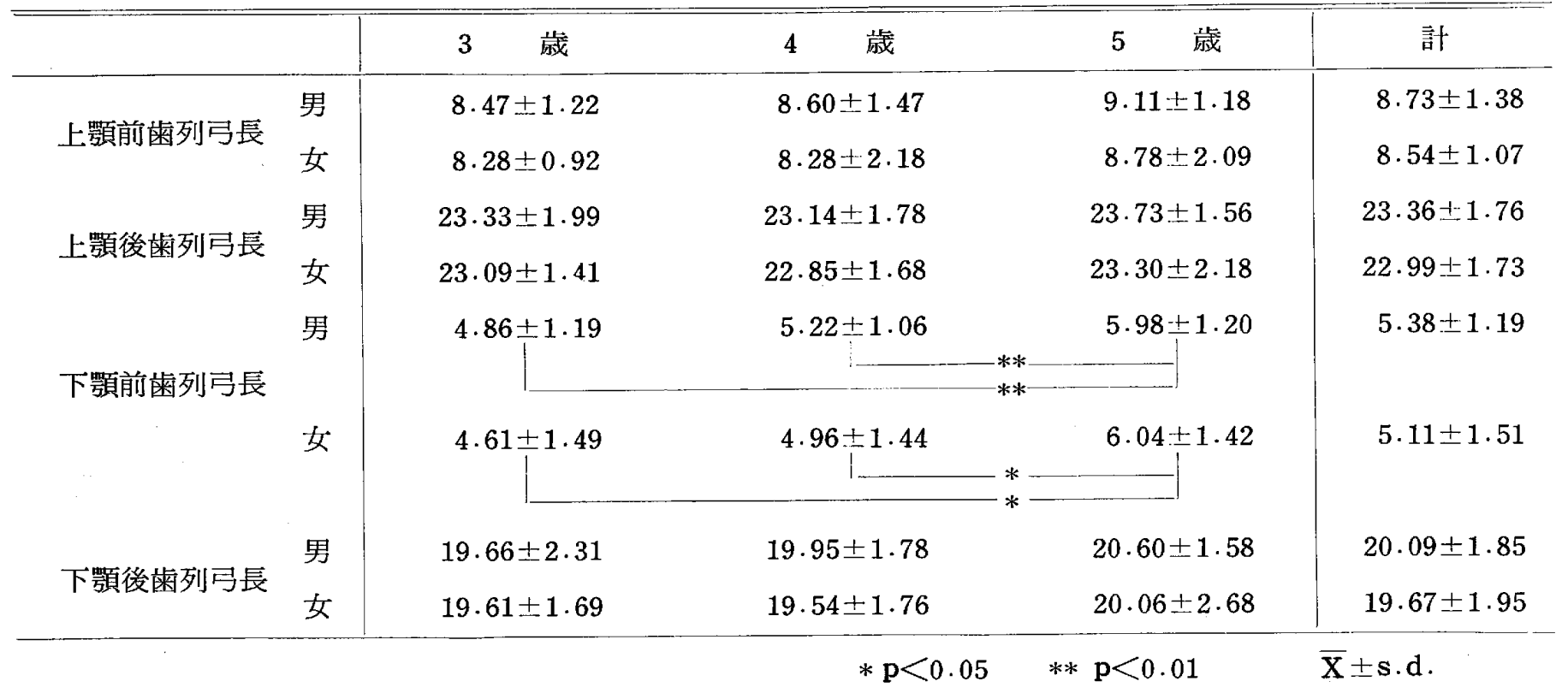

上䫛前歯列弓長

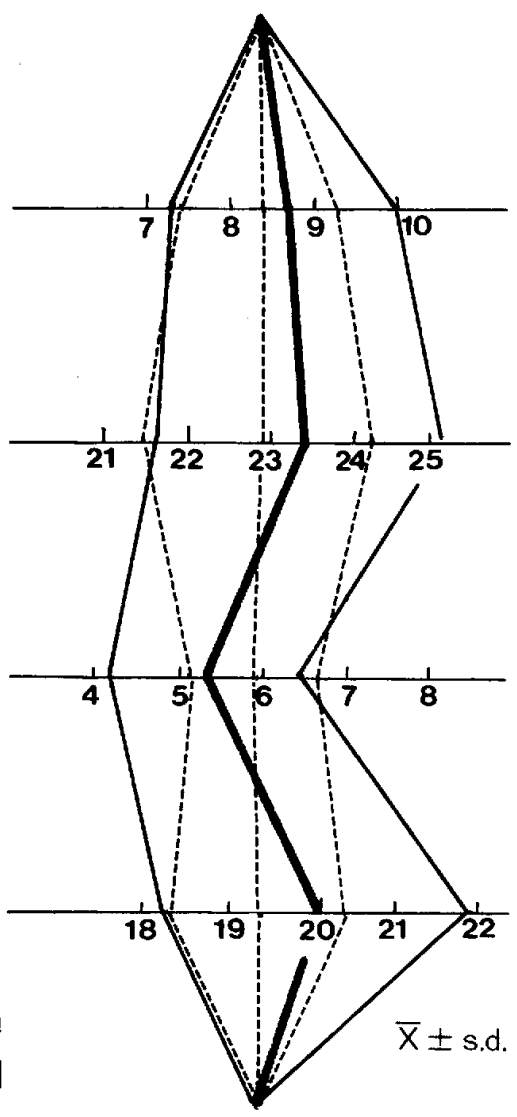

図 2 迷列弓長（男）

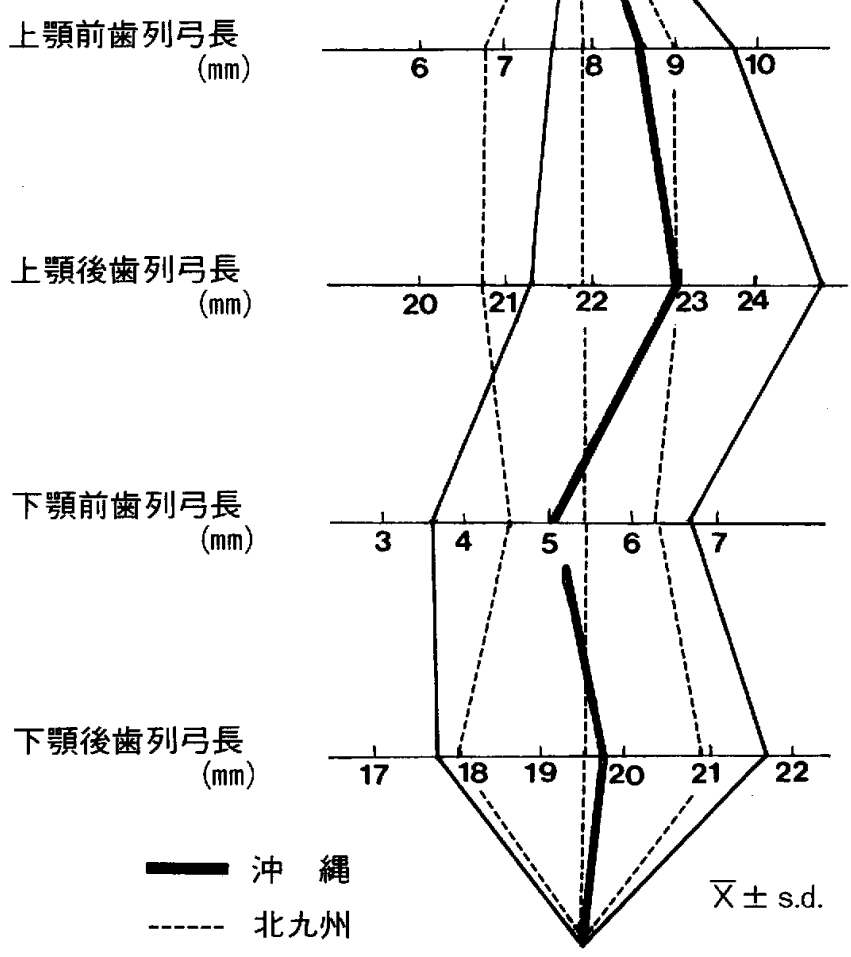

図 3 菌列弓長（女） 
表 8 乳曾列弓長径の沖縄および北九州幼児間の比較

\begin{tabular}{|c|c|c|c|c|}
\hline & \multicolumn{2}{|c|}{ 男 } & \multicolumn{2}{|c|}{ 女 } \\
\hline & 沖縄 & 北九 州 & 沖縄 & 北九州 \\
\hline 上 顎 前 歯 列 弓 長 & $8.73 \pm 1.38$ & $8.36 \pm 0.96$ & $8.54 \pm 1.07$ & $7.83 \pm 1.16$ \\
\hline 上顎 後 雬 列 弓 長 & $23.36 \pm 1.76$ & $22.84 \pm 1.35$ & $22.99 \pm 1.73$ & $21.85 \pm 1.14$ \\
\hline 下 顎 前 菌 列 弓 長 & $5.38 \pm 1.19$ & $5.93 \pm 0.74$ & $5.11 \pm 1.51$ & $5.37 \pm 0.86$ \\
\hline 下顎 後 歯 列 弓 長 & $20.09 \pm 1.85$ & $19.37+1.05$ & $19.67 \pm 1.95$ & $19.43 \pm 1.44$ \\
\hline & & $* \mathrm{p}<0.05$ & $* * \mathrm{p}<0.01$ & $\pm s . d$. \\
\hline
\end{tabular}

表 9

㐘 列 马幅

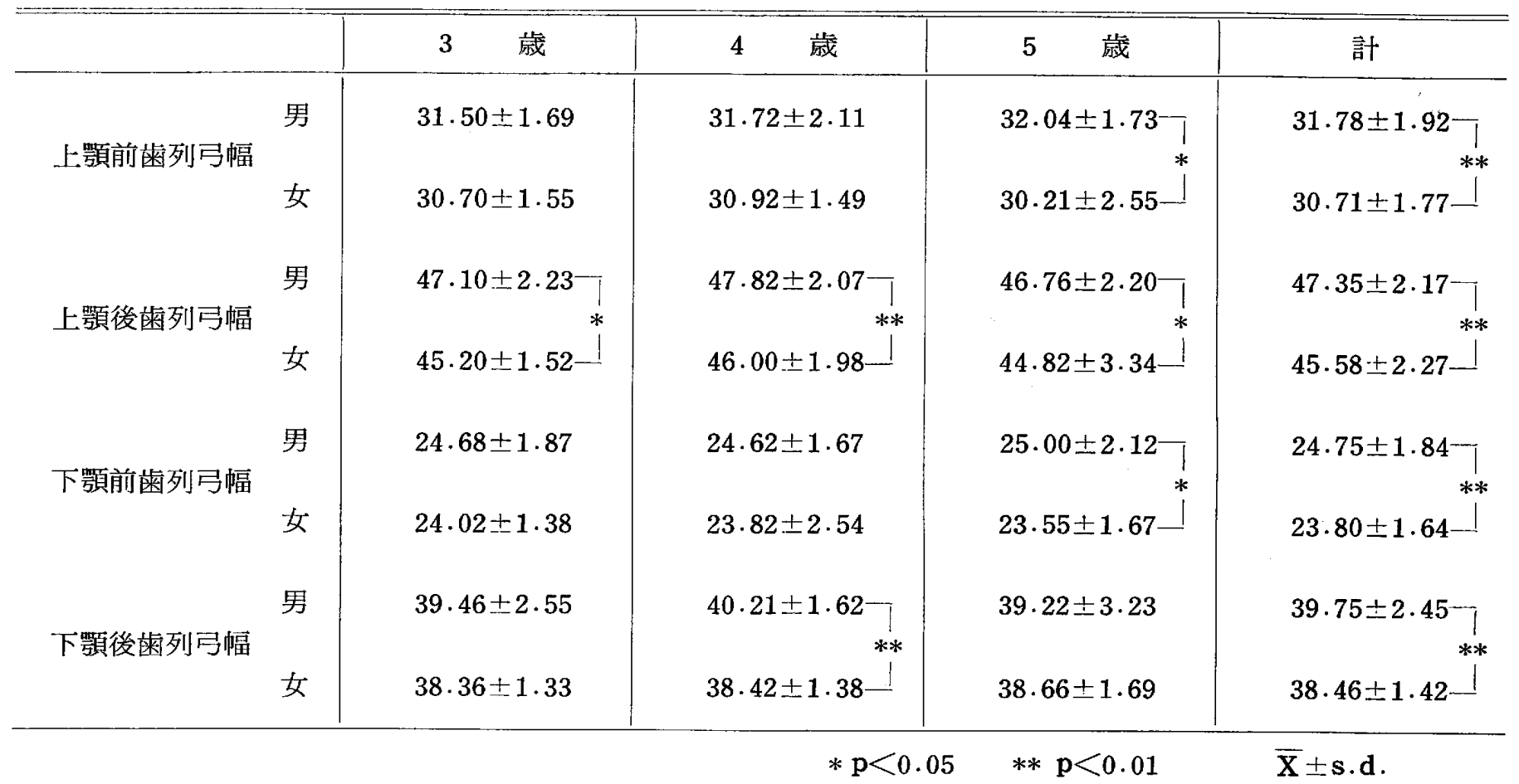

が32.04 $\pm 1.73 \mathrm{~mm}$ と有意 $(\mathbf{p}<0.05)$ 亿広い結果が示さ れた。上顎後歯列弓幅は, 女 $45.58 \pm 2.27 \mathrm{~mm}$ に対し, 男が 47.35 上 $2.17 \mathrm{~mm}$ と有意 $(\mathrm{p}<0.01)$ に広く，各年齢 に扔いも，すべて男が女より有意（p<0.01，0.05） に広かった。下顎前歯列马幅は，3〜5歳全体でみる と, 女 $23.80 \pm 1.64 \mathrm{~mm}$ に対し男が $24.75 \pm 1.84 \mathrm{~mm}$ と有

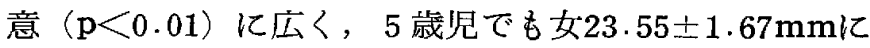
対し男が $25.00 \pm 2.12 \mathrm{~mm}$ と有意 $(\mathrm{p}<0.05)$ に広い結 果が示された。下顎後曾列弓幅についても同様に，女 $38.46 \pm 1.42 \mathrm{~mm}$ に対し男が39.75士2.45mm と有意（p $<0.01 ）$ に広く，また， 4 歳児でも有意（p<0.01）な
性差が認められた。しかしながら, 各年齢間では有意差 は認められず，ほほ同程度であった（表 9 )。

沖縄幼児の歯列引幅を北九州幼児と比較すると, 全般 的に男女とも，沖縄幼児が北九州幼児より広い傾向にあ り，特に，上顎前歯列弓幅の男女および，下顎前歯列弓 幅の男に有意差（p<0.01，0.05）が認められた（表10， 図 4,5 ).

\section{V . 画列马指数}

歯列弓指数は，表11に示した様に，各項目とも男女間 に著差はなく，また，年路間にも有意差は認められなか った。 
乳蒾列弓幅径の沖縄および北九州幼児間の比較

\begin{tabular}{|c|c|c|c|c|}
\hline & \multicolumn{2}{|c|}{ 男 } & \multicolumn{2}{|c|}{ 女 } \\
\hline & 油縄 & 北九州 & 沖 & 北九 州 \\
\hline 上 顎 前 歯 列 马 幅 & $31.78 \div 1.92$ & $30.59 \pm 1.68$ & $30.71 \pm 1.77$ & $28.87 \pm 2.37$ \\
\hline 上顎 後歯列 弓 幅 & $47 \cdot 35 \pm 2 \cdot 17$ & $46.61 \pm 2.09$ & $45.58 \pm 2.27$ & $45 \cdot 38 \pm 2 \cdot 34$ \\
\hline 下 顎 前 歯 列 弓 幅 & $24.75 \pm 1.84$ & $23.89+1.77$ & $23.80 \pm 1.64$ & $23 \cdot 23 \pm 2 \cdot 27$ \\
\hline 下顎 後 歯 列 弓 幅 & $39.75 \pm 2.45$ & $39.21 \pm 1.80$ & $38.46 \pm 1.42$ & $38.59 \pm 2.92$ \\
\hline
\end{tabular}

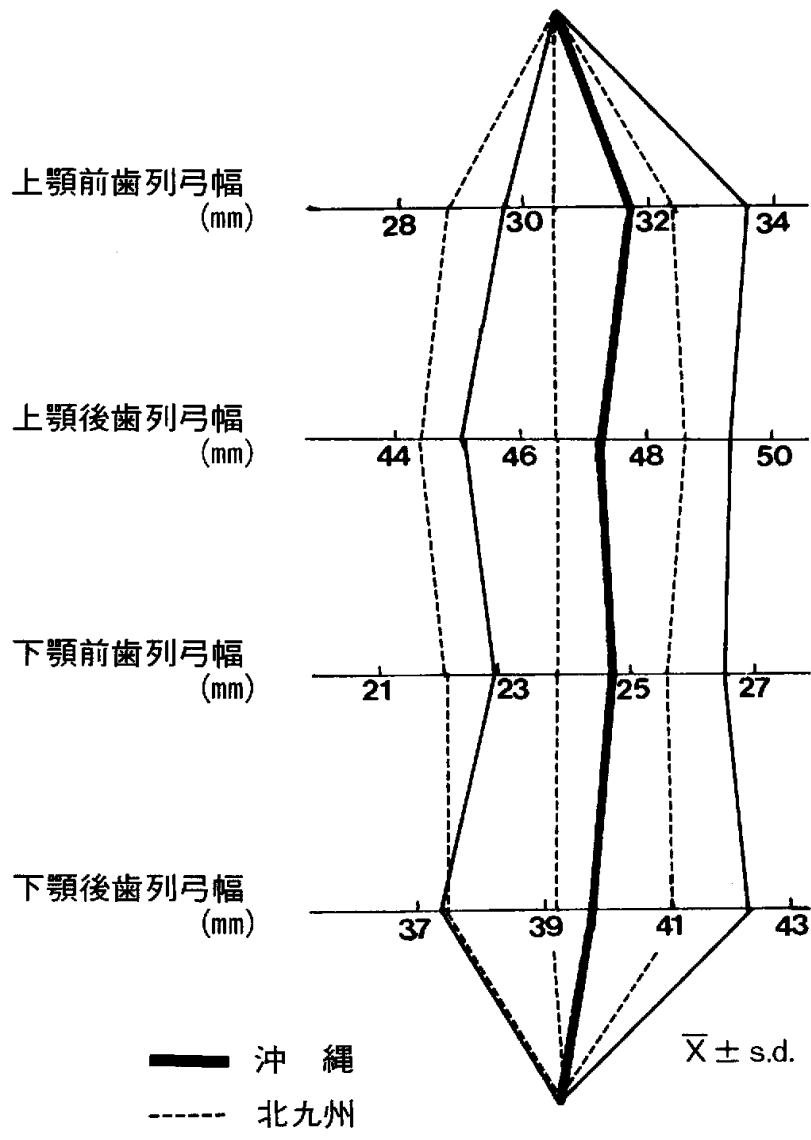

図 4 歯列弓幅（男）

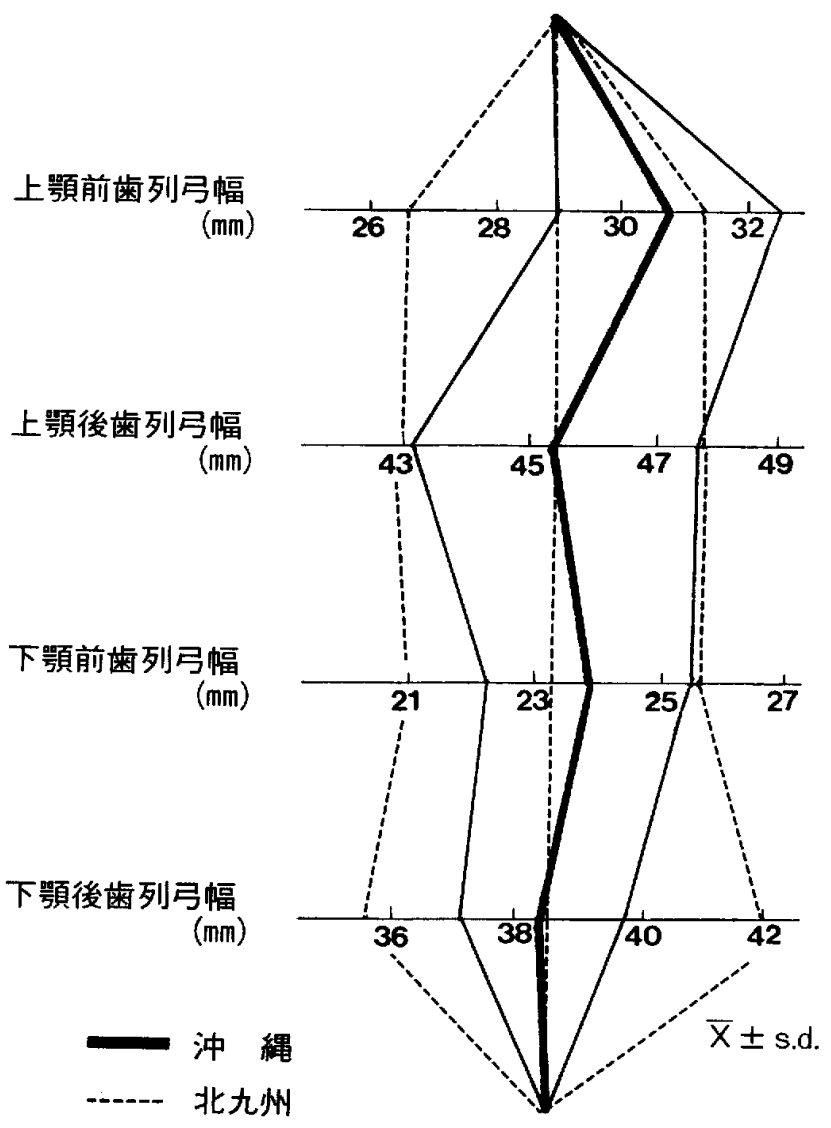

図 5 歯列弓幅（女）
沖縄幼坚の蒾列弓指数を北九州幼紧と比較すると, 上 頡前後雪列弓長および幅指数は, 男女とも沖縄幼児が北 九州幼坚より高い傾向にあり，特に上䫑前後䨋列弓幅指

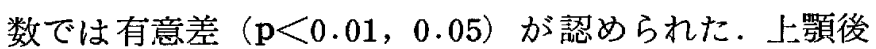
歯列弓指数では沖䋥幼児が北九州幼坚より若干高いよう であるが，上顎前歯列弓指数では差がなかった，下顎前 後歯列弓幅指数, 下顎後歯列弓指数では, 沖縄幼児が北
九州幼児より高い傾向にあり，特に下顎前後歯列弓幅指 数の男女ともに有意差（p<0.05）方認められた。しか しながら, 下顎前後霜列弓長指数, 下顎前歯列弓指数で は，逆に，男女とも沖縄幼児が北九州幼児より低い傾向 が見受けられ，特に男では有意差 $(\mathbf{p}<0.01)$ が認めら れた（表12，図 6,7 )。 
表11

歯 列 弓 指 数

\begin{tabular}{|c|c|c|c|c|c|c|}
\hline & & & 歳 & 歳 & 歳 & 計 \\
\hline \multirow{2}{*}{ 上顎前後菌列き長指数 } & \multirow{2}{*}{$(\%)$} & 男 & $36.24 \pm 0.19$ & $36.95 \pm-0.21$ & $38.28 \pm 0.17$ & $37.22 \pm 0.20$ \\
\hline & & 女 & $35.84 \pm 0.10$ & $35.96 \pm 0.23$ & $37.15 \pm 0.54$ & $36.19 \pm 0.26$ \\
\hline \multirow{2}{*}{ 上顎前後歯列幅指数 } & \multirow{2}{*}{$(\%)$} & 男 & $66.99 \pm 0.06$ & $56.35 \pm 0.10$ & $68.61 \pm 0.13$ & $67.17 \pm 0.11$ \\
\hline & & 女 & $67.83 \pm 0.06$ & $67.32 \pm 0.12$ & $67.46 \pm 0.21$ & $67.46 \pm 0.12$ \\
\hline \multirow{2}{*}{ 上顎前歯列马指数 } & \multirow{2}{*}{$(\%)$} & 男 & $26.82 \pm 0.25$ & $26.37 \pm 0.23$ & $28.33 \pm 0.11$ & $27 \cdot 30 \pm 0.20$ \\
\hline & & 女 & $27.07 \pm 0.06$ & $26.63 \pm 0.26$ & $28.88 \pm 0.72$ & $27.20 \pm 0.32$ \\
\hline \multirow{2}{*}{ 上顎後歯列寻指数 } & \multirow{2}{*}{$(\%)$} & 男 & $49.59 \pm 0.15$ & $48.43 \pm 0.13$ & $50.79 \pm 0.11$ & $49.37 \pm 0.14$ \\
\hline & & 女 & $51.07 \pm 0.06$ & $49.77 \pm 0.17$ & $52 \cdot 13 \pm 0.34$ & $50.55 \pm 0.19$ \\
\hline \multirow{2}{*}{ 下顎前後歯列弓長指数 } & \multirow{2}{*}{$(\%)$} & 男 & $24 \cdot 32 \pm 0.20$ & $25.74 \pm 0.36$ & $28.16 \pm 0.29$ & $26.19 \pm 0.32$ \\
\hline & & 女 & $23.46 \pm 0.31$ & $24.71 \pm 0.55$ & $29.67 \pm 0.28$ & $25.47 \pm 0.49$ \\
\hline \multirow{2}{*}{ 下顎前後歯列弓幅指数 } & \multirow{2}{*}{$(\%)$} & 男 & $62.57 \pm 0.08$ & $61.24 \pm 0.11$ & $64.05 \pm 0.28$ & $62 \cdot 36 \pm 0.17$ \\
\hline & & 女 & $62.62 \pm 0.09$ & $62.00 \pm 0.09$ & $61.00 \pm 0.18$ & $61.92 \pm 0.11$ \\
\hline \multirow{2}{*}{ 下蕦前歯列弓指数 } & \multirow{2}{*}{$(\%)$} & 男 & $19.46 \pm 0.28$ & $20.94 \pm 0.43$ & $23.76 \pm 0.29$ & $21.49 \pm 0.39$ \\
\hline & & 女 & $19.24 \pm 0.37$ & $20.40 \pm 0.60$ & $25.29 \pm 0.42$ & $21.15 \pm 0.57$ \\
\hline \multirow{2}{*}{ 下箱後菌列弓指数 } & \multirow{2}{*}{$(\%)$} & 男 & $49.80 \pm 0.32$ & $49.61 \pm 0.17$ & $52.83 \pm 0.26$ & $50.63 \pm 0.24$ \\
\hline & & 女 & $51.13 \pm 0.17$ & $50.88 \pm 0.19$ & $51.93 \pm 0.48$ & $51.16 \pm 0.24$ \\
\hline
\end{tabular}

$\bar{X} \pm$ s.d.

表12

柬列弓指数の沖縄および北九州奻児間の比較

\begin{tabular}{|c|c|c|c|c|c|}
\hline & & \multicolumn{2}{|c|}{ 男 } & \multicolumn{2}{|c|}{ 女 } \\
\hline & & 沖縄 & 北九 州 & 沖 & 北九州 \\
\hline 上顎前後歯列戸長指数 & $(\%)$ & $37.22 \pm 0.20$ & $35.95 \pm 0.08$ & $36.19 \pm 0.26$ & $35.20 \pm 0.12$ \\
\hline 上顎前後雬列吕愊指数 & $(\%)$ & $67.17 \pm 0.11$ & $65.65 \pm 0.11$ & $67.46 \pm 0.12$ & $62.65 \pm 0.11$ \\
\hline 上㖽前歯列弓指数 & $(\%)$ & $27.30 \pm 0.20$ & $27 \cdot 30 \pm 0.12$ & $27.20 \pm 0.32$ & $27.38 \pm 0.20$ \\
\hline 上顎後歯列局指数 & $(\%)$ & $49.37 \pm 0.14$ & $49.08 \pm 0.12$ & $50.55 \pm 0.19$ & $48.64 \pm 0.12$ \\
\hline 下䫁前後啬列弓長指数 & $(\%)$ & $26.19 \pm 0.32$ & $29.17 \pm 0.07$ & $25.47 \pm 0.49$ & $27.21 \pm 0.09$ \\
\hline 下顎前後歯列弓幅指数 & $(\%)$ & $62.36 \pm 0.17$ & $60.82 \pm 0.09$ & $61.92 \leftrightarrows 0.11$ & $59.93 \pm 0.24$ \\
\hline 下㖽前菌列弓指数 & $(\%)$ & $21.49 \pm 0.39$ & $24.91 \pm 0.23$ & $21.15 \pm 0.57$ & $23.00 \pm 0.16$ \\
\hline 下顎後歯列弓指数 & $(\%)$ & $50.63 \pm 0.24$ & $50.58 \pm 0.09$ & $51 \cdot 16 \pm 0.24$ & $49.60 \pm 0.10$ \\
\hline
\end{tabular}




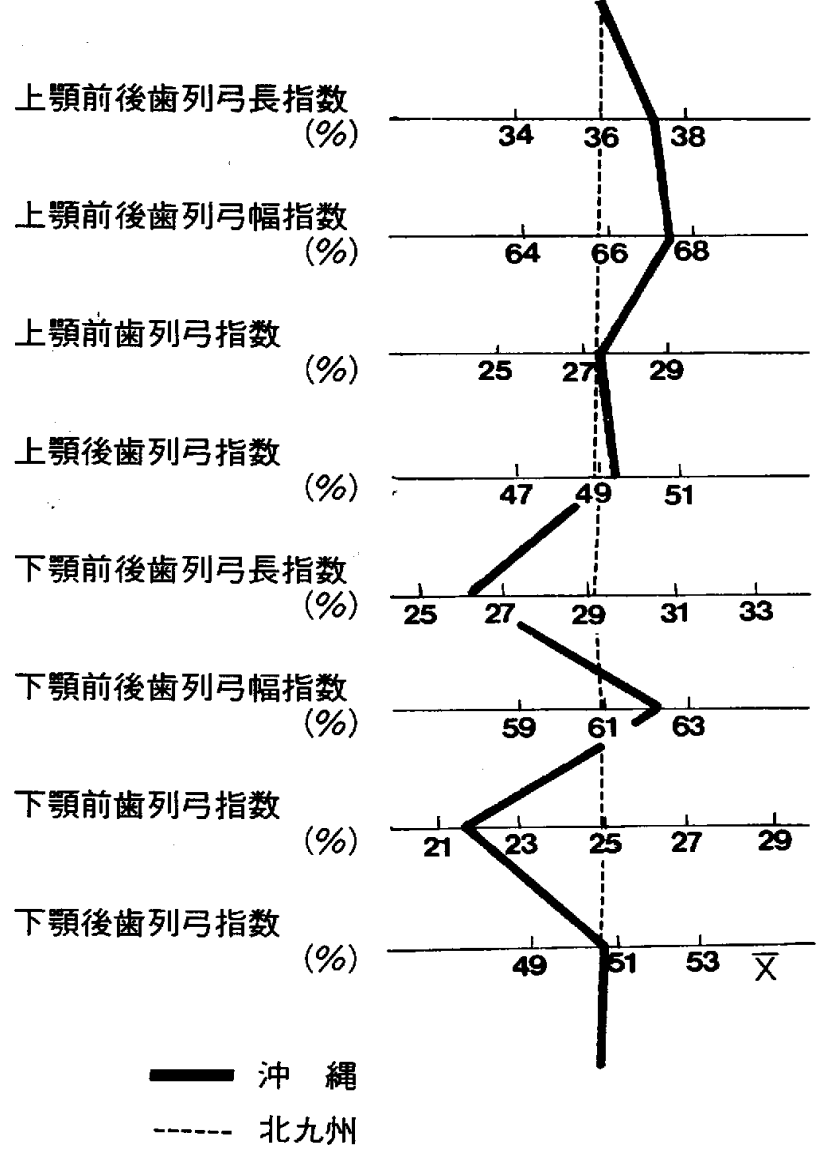

図 6 歯列马指数（男）

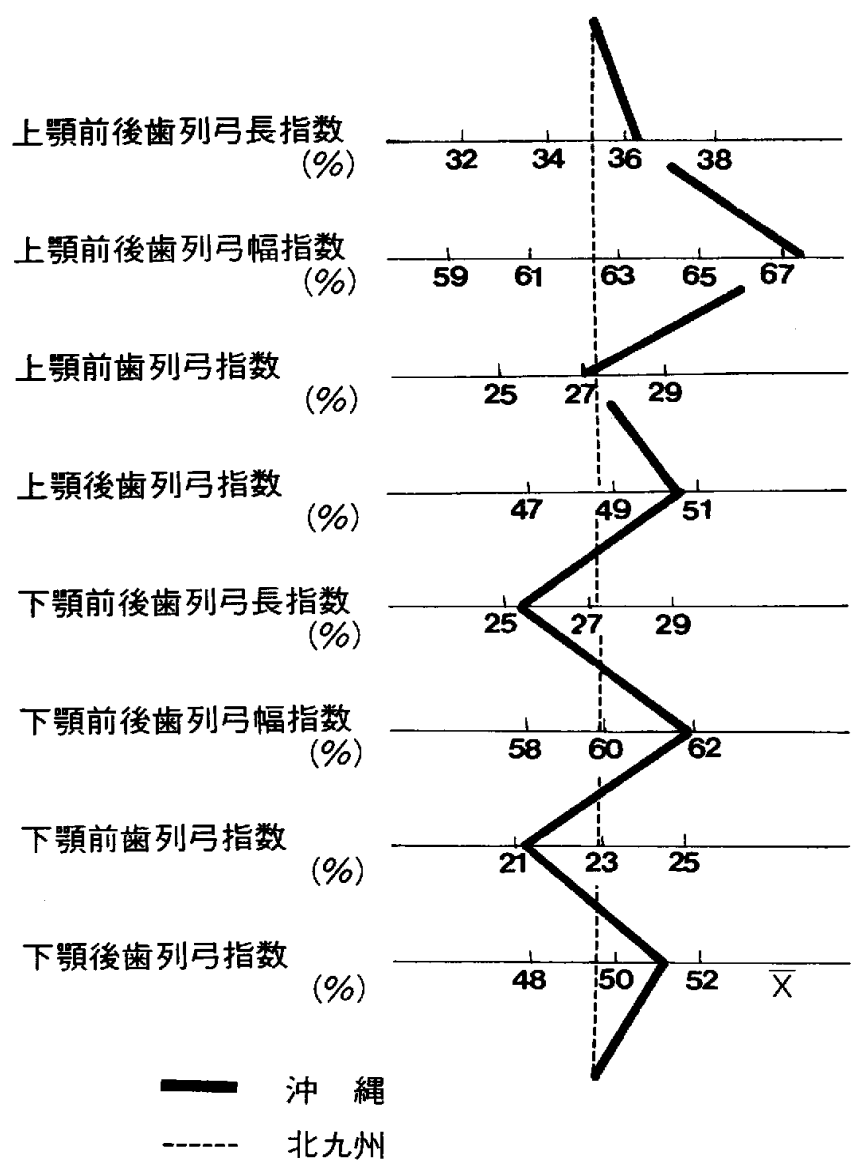

図 7 粜列弓指数（女）

\section{考察}

従来より教室では, 歯列弓や口蓋の形質について, 九 州各地, 離島を始め, 沖縄, 台湾原住民などの調查を行 なって抢り，その結果，民族的，地域的特徽があること を報告してきた1ー8)。しかしながら，その多くは成人を 対象とした永久雨列についてであり，乳雪列について は，資料採取の困難さや，顎の成長発育による変動が大 きいととなどから，あまり見受けられない，さらに，計 測基点や計測方法も報告者により様々であり，比較検討 のために計測方法をどれかに統一すると，極めて少ない ものになってしまう，今回，著者は沖䋲県在住（いわゆ る内地から移住してきた者は対象としない）の幼㧛の乳 歯列弓について, 種々の角度より検討を行ない, 計測方 法の一致をみる項目のみ他の報告值と比較した。また， 沖縄幼児の乳䨑列弓の諸形質についての報告は全く認め られないので，いわゆる内地の幼児と比較することで， 特徽を明らかにしたい。

乳䨑列弓における不正咬合については，乳歯が代生歯 であること, 歯間空陌の存在やその変化のため基準がと
りにくいとと, 永久画列より出現頻度が低く著明でない こと，などの理由によりあまり多くの報告は認められな い. 兼松 $(1973)^{14}{ }^{4}$ は，第 2 乳臼蒾の咬合関係では，年 㱓的に推移するので, 前䨑部の不正によって一定の基準 を設け分類している．著者は，沖縄幼児を内地幼児と比 較するために，兼松（1973１１4（分類基準を参考にし た。樑田 $(1952)^{15}$ ' は, 東京都内の 19,149 名 $(0 \sim 6$ 歳 $)$ を対象に報告を行なっているが，捻転を含め切端咬合を 除外しているので，著者が集計しな抢すと，正常咬合者 の割合は，3 歳で男 $90.9 \% ， 女 92.5 \% ， 4$ 歳で男 90.9 $\%$ ，女 $89.3 \% ， 5$ 歳で男 $90.5 \%$ ，女 $91.2 \%$ ，不正咬合の 発現頻度は，上顎前突，過蓋咬合，反対咬合，交叉咬合， 開口の順に，3 歳男一1.6\%，3.2\%，2.1\%，0.5\%， $1.6 \%, 3$ 歳女一 $0.8 \%, 2.9 \%, 3.1 \%, 0 \%, 0.8 \%, 4$ 歳男-1.6\%, $3.1 \%, 2.8 \%, 0.1 \%, 1.5 \%, 4$ 歳女一 $1.4 \%, 2.9 \%, 5.1 \%, 0 \%, 1.4 \%, 5$ 歳男 $-1.7 \%$, $2.8 \%, 2.6 \%, 0.1 \%, 2.3 \%, 5$ 歳女一 $1.4 \%, 2.0 \%$, $4.0 \%, 0.1 \% ， 1.4 \%$ となっている.一色ら $(1970)^{131}$ は 3 歳児 121 名について, 正常咬合者の割合は, 男 45.0 $\%$ ，女 $55.9 \%$ ，不正咬合の発現頻度は，切端咬合一男 
$16.0 \%$ ，女 $5.1 \%$ ，上顎前突一男 $9.8 \%$ ，女 $12.5 \%$ ，過蓋 咬合一男 $9.8 \%$ ，女 $21.9 \%$, 反対咬合一男 $12.2 \%$ ，女 4.7 $\%$ ，交叉咬合一男 $4.9 \%$ ，女 $0 \%$ ，開口一男 $2.4 \%$ ，女 0 $\%$ と報告している。 また，一色ら (1971) $\left.{ }^{16}\right)^{6}$ は，5歳児 80名でも同様の分類で行ない, 男女合計の值であるが， 正常咬合の割合は $49.4 \%$, 不正咬合では，上顎前突一 $3.9 \%$, 過蓋咬合一 $36.4 \%$, 反対咬合一 $6.5 \%$, 交叉咬合 $-1.3 \%$ ，開口一 $2.6 \%$ あったとしている．兼松 (1973) 14)は, 109名について 3 歳から 5 歳まで Cohort 観察 を行ない報告している。この中で, 彼は, 䀞蝕により咬 合状態に変化が生ずる，つまり経年的な臼歯部の歯冠萌 壊の増加により過蓋咬合の増加が認められると述べてい る. そこで, 兼松 (1973) 14) の結果汃ら, 歯冠崩壊アリ を除き集計しなおすと，3歳の時点で，正常咬合者は $63.6 \%$, 不正咬合では, 切端咬合一 $3.4 \%$, 上買前突一 $12.5 \%$ ，過蓋咬合一 $6.8 \%$, 反対咬合一 $8.0 \%$ ，交叉咬合 $-1.1 \%$ ，開口- $4.5 \%$ である．沖縄幼坚の乳歯列咬合状

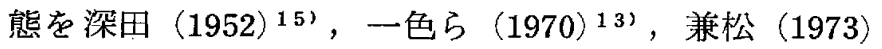
14) の值と比較すると，3歳児では, 沖縄幼児の正常咬 合者の割合は男 $43.8 \%$ ，女53.8\%で，一色ら(1970) ${ }^{131}$ ， 兼松 $\left.(1973)^{14}\right)$ より $10 \%$ 近く低く, 深田 $(1952)^{15)}$ 上り 約40\%低い，4歳児では，男 $63.4 \%$, 女65.7\%で, 深田 $(1952)^{15)}$ より $20 \sim 30 \%$ 低い，5歳児では，男 $88.0 \%$ ， 女76.9\%で，深田 $(1952)^{15)}$ より若干低いが，一色ら $(1971)^{16)}$ より $30 \%$ 近く高い，不正咬合出現頻度に 関し ては, 沖縄の 3 歳児は上顎前哭, 過蓋咬合が男女とも 10 \%台と他項目より高く，一色ら（1971）16) とほぼ同率で あるが兼松 $(1973)^{14)}$ よりやや高率, 深田 $(1952)^{151}$ よ りかなり高率である. 沖縄の 4 歳児では，上顎前突にか わり切端咬合の割合が高くなり，切端咬合と過蓋咬合が 1 割強を占め, 深田（1952）151 よりかなり高率である. 沖䋥の 5 歳児では, 切端咬合, 過蓋咬合が他項目よりは 高いが，低年齢児よりかなり低率である。しかしなが ら，樑田 $(1952)^{15)}$ と比較すると，まだ若干高率であ る. 深田 $(1952)^{15}$ の值は例数が多いのでコントロール に適していると思われるが，深田（1952）15) も言うよう に，正常咬合に対する定義が一定していないため，比較 的明瞭なる不正咬合のみを選んだ結果, 正常咬合者が90 \%を超す高率となったのであろう．したがって沖縄幼児 より，いずれの不正咬合者の割合も低い傾向にある。さ らに, 沖縄幼児の正常咬合者は加㱓に伴って増加し, 逆 に, 上顎前突, 過蓋咬合が減少している，ての原因とし ては，増齢に伴う下顎の前方発育や不良習癖の中止など が考えられる. また, 一色ら (1971) 16) との差は, 沖縄
幼児が眯蝕のない者であるのに対し，一色ら (1971) 16) も述べているように，漓蝕進行による雪冠崩壊が，過蓋 咬合を増加させた分，正常咬合者が減少しているためで ある。

乳茵列弓の歯間空隙には, 上顎では乳犬菌の近心，下 顎では乳犬歯の遠心に出現する, Primate space（霊長 空陌，以下 PS と略す）と PS 以外の額の成長によって 生じたと思われる Developmental space（成長空隙, 以下 DS と略す) がある. との歯間空隙については, 後 継永久歯列の排列に大きな役割を果すという観点から， 予防矯正的な研究が多く見受けられる $11,13-14,17-26)$. その中で, Baume (1950) ${ }^{17}$ は, PS は遺伝的に決定さ れるものであるとし，個人の有する歯間空隙は不変であ

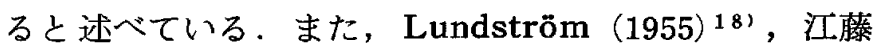
(1969） ${ }^{21)}$ も，遺伝的要因のあるととを報告している. さらに，顎の成長発育の時期的，量的なものも個体差が あるととを考元ると, 当然, 民族的, 人種的な特徴があ るものと思われる。

沖縄幼児の歯間空隙出現頻度は, 上頻では各年跉, 男 女とも PS とDS の混合型が最も高く, 次いで, PS の み，閉鎖型の順で，DS のみは僅か 1 名にすぎない，下 顎では, $3 \sim 5$ 歳全体についてみると, 閉鎖型（男30.5 $\%$ ，女52.5\%)，PS+DS (男 $37.8 \% ， 女 21.5 \%$ ) が高率 を占めている，年粈別てみると，男では， 3 歳児の PS のみが $43.8 \%$ と高いが，4 歳 $(22.0 \%) ， 5$ 歳 (16.0\%) と低くなる傾向がみられ，その分， PS+DS むしくは DS のみが高率となっている．閉鎖型は 29〜32\%で一定 している，女では， 3 歳児の閉鎖型が $76.9 \%$ と著しく高 $く, 4$ 歳 $(57.1 \%), 5$ 歳 $(15.4 \%)$ と年秢が高いほど 低率傾向にある.PS+DS もしくは DS のみに関して

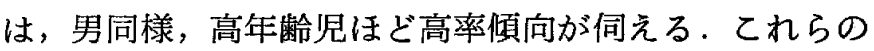
所見は，男女とも，高年歯览になるにつれて空隍の増加 を表わしておう，量的なものはわからないが，顎骨や歯 槽骨の成長発育の結果と思われる。

沖縄幼児の歯間空隙の型別出現頻度を他の報告と比較 すると，上顎では，3歳児について，沖縄幼坚は PS+ DS が男 $62.5 \%$, 女 $46.2 \%$ で，一色ら $(1970)^{13}$ の男 $74.5 \%$ ，女 $79.1 \%$ ，兼松 $(1973)^{14}$ の94.6\%よりかなり 低率である． 4 歳児については，沖縄幼児の PS + DS 型 が男 $58.5 \%$ ，女51.4\%であり，兼松（1973（14) の87.5\% より $30 \%$ 程度低い，5歳児については, 沖縄幼児の PS $+\mathrm{DS}$ 型が男 $80.0 \%$ ，女 $69.2 \%$ であり，兼松 $(1973)^{14)}$ の76.8\%とほほ同率である. $3 \sim 5$ 歳览全体では, 沖縄 幼児の PS+DS 型が男 $65.9 \%$ ，女54.0\%であり，武田 
$(1972)^{24 \prime} の 92.0 \% よ り$ 䄪30\%低いが，小野ら $(1960)^{111}$ の69.4\%より若干低い。下額では，3歳児について，沖 縄幼児は男はPS のみ $(43.8 \%)$ ，女は閉鎖型 $(76.9 \%)$ が最も高いが，一色ら (1970 ${ }^{13)}$ は PS+DS が男55.3 $\%$ ，女53.8\%と，兼松 $(1973)^{14}$ は同じく PS+DS が $71.4 \%$ とそれぞれ最高率を示している．4 歳児について は，沖縄幼児の男は PS+DS が $43.9 \%$ ，女は閉鎖型が

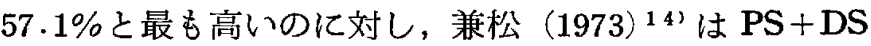
が66.1\% と，沖縄幼児よりかなりの高率である． 5 歳児 では，男は PS+DS が36.0\%，女は DS のみが38.5\% と最も高いが，兼松(1973) ${ }^{14}$ )のPS+DS (50.0\%) よ り20\%弱低率である. 3 〜 歳児全体についてみると, 沖縄幼児は閉鎖型（男 $30.5 \% ， 女 52.5 \%$ ), PS+DS（男 $37.8 \%$ ，女 $21.3 \%)$ が高率を示しているが，小野ら（19 60) ${ }^{11}$ はPS PS が53.6\%と半数を占め,閉鎖型は 24.7 $\%$, 武田 $(1972)^{24)}$ は, PS+DS が75.0\%と 4 分の 3 を 占め，閉鎖型は $8 \%$ と低く，沖䋲幼児より，PS+DS で はかなりの高率，閉鎖型ではかなり低率である．以上の ように，報告者によって菌間空鄚の出現頻度は差が認め られ，上顎では，PS+DS が最も高率である点では，一 色ら $(1970)^{13}$ ，兼松 $(1973)^{14)}$ ，武田 $(1972)^{24}$ ，小 野ら（1960）11) の報告と同㥞の傾向であるが，沖緡幼児 の方が低率である．下顎では，沖縄幼児は閉鎖型が高率 なのが特徵的で，一色ら $(1970)^{13}$ ，兼松 $(1973)^{14)}$, 武田 $(1972)^{24)}$ ，小野ら $(1960)^{11}$ と異なる所見である.

Terminal plane そついて, Baume (1950) ${ }^{17}$ は, 第 2 乳臼䨑の形態的変位により差を生じ， $3 \sim 5$ 歳半で は, Terminal plane は一定であったとし, Calsen ら $(1960)^{27}$ は，臼歯の前後関係に影響する因子は，下顎 の成長速度, 上顎の成長速度, Terminal plane, Le-

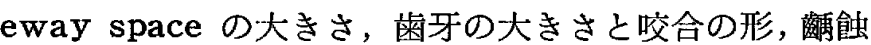
乳歯の早期䨗失，習癖環境因子などがあると報告されて いる. また, Terminal plane を人種的にみると, アメ リカ人は straight type であり, エスキモー人, 北ア メリカインディアン，ギリシャ人などは,乳歯の咬合面， 特に乳犬䨒の尖頭が咬耗して咬頭干渉が除かれ，下顎が 容易に前方位をとり，前霜部で edge to edge となっ て, Terminal plane は mesial step type とると 言われている。

沖縄幼児の Terminal plane の型別出現頻度は, 各 年秢とも VV 型が最も高く，男女同傾向である。沖縄 幼児を他の報告と比較すると，3歳児では，沖縄幼児が VV 型一男 $43.8 \%$ ，女 $69.2 \%, \mathrm{MM}$ 型一男 $37.5 \%$ ，女 $30.8 \%, \mathrm{VM}$ 型一男 $18.8 \%$ ，女 $0 \%, \mathrm{MM}$ 型，VD型，
MD 型は男女乞も0\%であるのに対し，一色ら（1970） 13) は VV 型一男50.0\%，女66.2\%， MM 型一男7.2\%， 女 $12.9 \%, \mathrm{DD}$ 型一男 $9.5 \%$ ，女1.6\%，VM 型一男 21.4 $\%$, 女 $14.5 \%$, VD 型一男 $11.9 \%$, 女 $4.8 \%, \mathrm{MD}$ 型一 男 $0 \%$ ，女 $0 \%$ ，兼松 $(1973)^{14 \prime}$ はV V 型- $30.4 \%$ ， $\mathrm{MM}$ 型-28.6\%，DD 型-7.1\%，VM 型-12.5\%，VD 型-16.1\%，MD型-5.4\%であり，沖縄奻児の VV 型 出現頻度は，一色ら（1970（13) と同程度で兼松（1973） 14)より高率， MM 型は一色ら $(1970)^{131}$ ，兼松 (1973) 14)より高率，他は低率である。4 歳児では, 沖縄幼児 の VV 型一男 $61.0 \%$, 女 $62.9 \%, \mathrm{MM}$ 型一男 $31.7 \%$, 女 $31.4 \%, \mathrm{DD}$ 型一男 $4.9 \%$ ，女 $2.9 \%, \mathrm{VM}$ 型一男 2.4 $\%$ ，女 $2.9 \%, \mathrm{VD}$ 型， MD 型は男女とも0\%であり， 兼松 $(1973)^{14)}$ の VV 型一 $26.8 \%, \mathrm{MM}$ 型-2 $28.6 \%$, $\mathrm{DD}$ 型- $14.3 \%, \mathrm{VM}$ 型-19.6\%, VD 型-7.1\%, MD 型一3.6\%に比して，VV 型，MM 型で高率，他は低率 である，5歳児では，沖緡幼児が VV 型一男56.0\%，女 $46.2 \%, \mathrm{MM}$ 型一男 $40.0 \%$, 女 $23.1 \%, \mathrm{DD}$ 型一男 0 $\%$ ，女 $23.1 \% ， \mathrm{VM}$ 型一男 $4.0 \%$ ，女 $7.7 \%$, VD 型， MD 型は男女とも $0 \%$ あるあのに対し，一色ら（1971） 16) は VV 型一24.1\%， MM 型一 $24.1 \% ， \mathrm{DD}$ 型一 10.3 $\%, \mathrm{VM}$ 型一 $20.7 \%, \mathrm{VD}$ 型-13.8\%, MD 型-6.9\%, 兼松 $(1973)^{14)}$ はV V 型-23.2\%， MM 型-33.9\%， $\mathrm{DD}$ 型-7.1\%，VM 型-21.4\%，VD 型-7.1\%， MD 型一 $7.1 \%$ であり，沖縄幼児の VV 型出現頻度は，一色 ら $(1971)^{16)}$ ，兼松 $(1973)^{14)}$ より高率，MM 型は兼松 (1973) 14) と同程度で一色ら $(1971)^{16)}$ より高率，DD型 は一色ら $(1971)^{162}$ ，兼松 $(1973)^{14 !}$ と大差ないが，他 は低率である，3〜 5 歳全体についてみると，沖縄幼児 の VV 型一男 $56.1 \%$ ，女 $60.6 \%, \mathrm{MM}$ 型一男 $35.4 \%$, 女 $29.5 \%$, DD 型一男 $2.4 \%$ ，女 $6.6 \%$, VM 型一男 6.1 $\%$ ，女 $3.3 \% ， \mathrm{VD}$ 型，MD 型は男女とも0\%であり， 小野ら $(1960)^{111} の \mathrm{VV}$ 型一 $59.1 \%, \mathrm{MM}$ 型-19.1\%， $\mathrm{DD}$ 型 $-4.6 \%, \mathrm{VM}$ 型-9.1\%，VD 型-8.1\%， MD 型 $0 \%$ に比して，VV 型，DD 型，MD 型でほぼ同率， $\mathrm{MM}$ 型は高率であるが，VM 型，VD 型は低率である。 以上を小括すると，3〜5歳のトータルでみると小野ら $(1960)^{11 '}$ の報告と類似しているが，年踰別でみると，

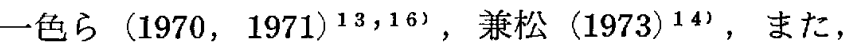
Friel (1927) ${ }^{28)}$ が示した, 経年的に mesial stap の程 度が強くなったり mesial stap type へ移行するものの 増加が認められず，各年齢児とも vertical type, mesial stap type はほぼ同率を呈している。

霆列弓長の性差に関しては，一色ら（1970（13'は男子 
は女子より大きい値を示し，その差は幅徍より大きかっ た（有意差の判定はしていない）と述べている．丸山 (1971） ${ }^{29}$ は，上顎乳中切菊と第 2 乳臼歯間距離のみ有 意差が認められたが，他はなかったとし，小野ら(1960) 11)や加藤（1979）29）らは長径には有意な性差を誓めて いない，当教室で過去に行なった乳雨列の計測において は, 閒司の幼稚園児（3～5 歳）を対象とした北島（19 74) ${ }^{9}$ や，北九州市在住の 精神発達遅滞児の口腔形質を 調べた安藤（1984）10) らがあるが，北島·(1974） ${ }^{91}$ は， 5 歳呪のみ有意差があったと, 安藤 $(1984)^{10}{ }^{0}$ は, 犬歯 部，第 1 乳臼歯部，第 2 乳自蒋部のいずれにも有意の性 差が認められたと，それぞれ厗告している。乙れらの成 績を総合すると，歯列马長は，男の方が女より長い僋向 が譛められてはいるが，僅かな量上考えられよう，著者 が行なった，沖縄奶児の歯列弓長においても，3〜5歳 の上・下顎ともに男児が僅かに長い程度で，有意差はな く，他の研究者之同様な傾向之思われる.

沖縄幼児の雪列弓長を他の報告と比較すると，3 歳児 では，上䪽前歯列亏長は男 $8.47 \mathrm{~mm}$ ，女 $8.28 \mathrm{~mm}$ で，小 野ら（1960）11)の8.92mmよりやや短いが，兼松 (1973) ${ }^{14)}$. $8.00 \mathrm{~mm}$ 上りやや長い，上顎後茵列弓長は男 23.33 $\mathrm{mm}$, 女23.09mmで, 小野ら $(1960)^{11}$ の $23.40 \mathrm{~mm}$ よ りやや短いが, 兼松 $(1973)^{14}$ の $22.70 \mathrm{~mm}$ よりやや長 い. 下顎前歯列弓長は男 $4.86 \mathrm{~mm}$ 、女 $4.61 \mathrm{~mm}$ で，兼松 (1973) ${ }^{14}$ 'の 4 .93mm, 加藤 $(1979)^{30}$ ) の男 $4.61 \mathrm{~mm}$, 女4.51mm と大差ない.下顎後崡列可長は男 $19.66 \mathrm{~mm}$, 女19.61mmで, 兼松 (1973) 14)の19.14mmよりやや長 い. 4 歳児では，上類前歯列長は男 $8.60 \mathrm{~mm}$, 女 8.28 $\mathrm{mm}$ で，小野ら $(1960)^{11)} 8.61 \mathrm{~mm}$ と美はないが，兼 松 (1960) $)^{14}$ の7.79mm より長い。上顎後苗列局長は男 $23.14 \mathrm{~mm}$ ，女 $22.35 \mathrm{~mm}$ で，小野ら (1960) ${ }^{11}$ の 23.29 $\mathrm{mm}$ 上りやや短いが，兼松 $(1973)^{14}$ の $22.37 \mathrm{~mm}$ 上り やや長い．下嚬前雨列弓長は男 $5.22 \mathrm{~mm}$, 女 $4.96 \mathrm{~mm}$ で, 兼松 (1973) ${ }^{14}$ ) $4.84 \mathrm{~mm}$, 加藤 $(1979)^{30}{ }^{30}$ の男 $4.46 \mathrm{~mm}$, 女 $4.53 \mathrm{~mm}$ よりやや長い，下顎後歯列弓長は，男 19.95 $\mathrm{mm}$, 女19.54mmで, 兼松 (1973) 14) の19.01mmより やや長い， 5 歳罗では, 上顎前雨列弓長は, 男 $9.11 \mathrm{~mm}$, 女 $8.78 \mathrm{~mm}$ で，小野ら $(1960)^{11)}$ の $8.26 \mathrm{~mm}$ ，兼松 (19

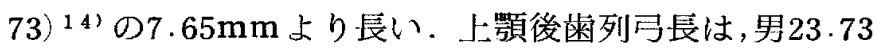
$\mathrm{mm}$, 女23.30mm で, 小野ら (1960) ${ }^{11)} 22.64 \mathrm{~mm}$, 兼松 $(1973)^{14)} の 21.98 \mathrm{~mm}$ 上り長い, 下顎前歯列弓は, 男 $5.98 \mathrm{~mm}$, 女 $6.04 \mathrm{~mm}$ で, 兼松 $(1973)^{14)}$ の $4.83 \mathrm{~mm}$, 加藤 $(1979)^{30}$ ' の男 $5.09 \mathrm{~mm}$, 女 $4.44 \mathrm{~mm}$ より長い.下 顎後蒾列弓長は, 男 $20.60 \mathrm{~mm}$, 女 $20.06 \mathrm{~mm}$ で, 兼松
$(1973)^{14)}$ の18.85mm より長い. $3 \sim 5$ 歳児の総計につ いてみると，下顎前歯列弓長は，男 $5.38 \mathrm{~mm}$, 女 $5.11 \mathrm{~mm}$ で, 小野ら (1960）11’の5.51mmよりやや短いが, 逆に 下顎後崡列弓長は, 男 $20.09 \mathrm{~mm}$, 女 $19.67 \mathrm{~mm}$ で, 小野 ら (1960) ${ }^{111} の 19.59 \mathrm{~mm}$ よりやや長い。また，北九州 幼児と比較した結果では，下顎前菌列長は，沖縄幼児 が北九州幼児より短く，上顎前および後霜列弓長，下顎 後歯列户長は，沖縄幼児が北九州幼归上り長い傾向が明 磪に示され（図 8），小野ら $(1960)^{11}$ 'の報告值との比 較と同傾向である。
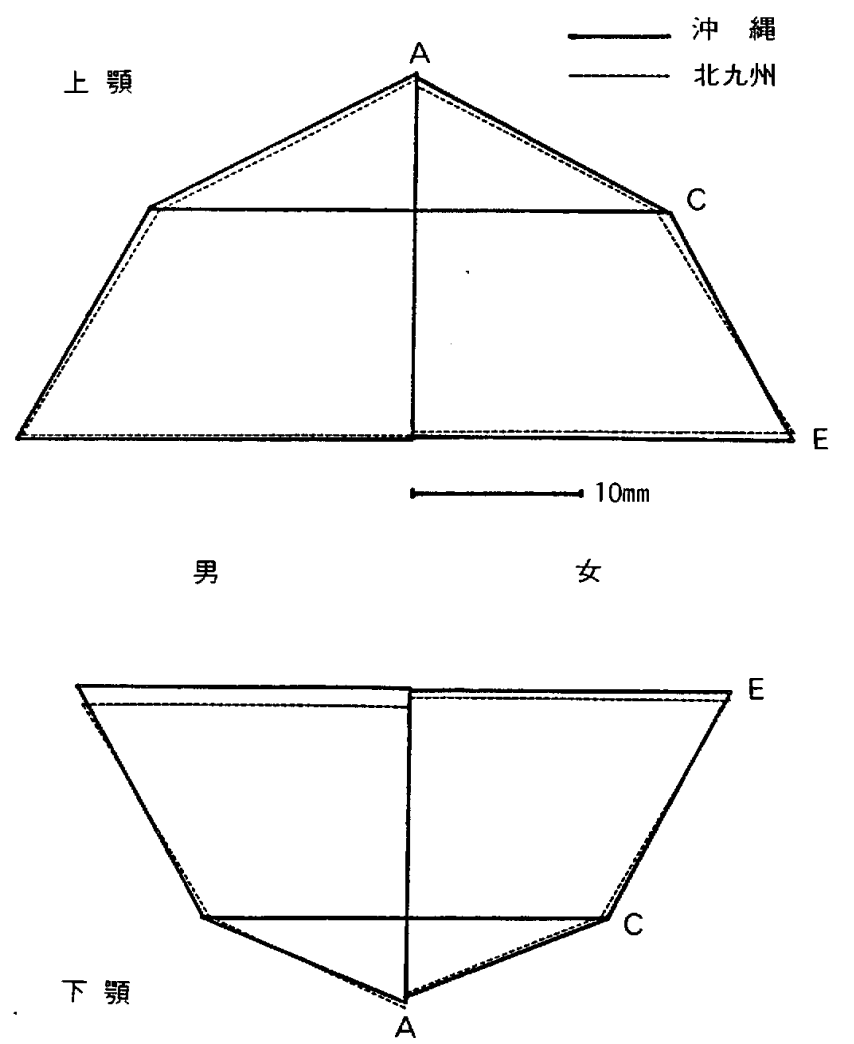

図8 沖縄幼児と北九州幼児における上下罰乳霜列 弓 (霜列弓長, 歯列弓幅) の比較

歯列弓幅の性差に関しては，一色ら（1970） ${ }^{131}$ は男子 が女子より大きい，小野ら（1960）111は，男が女より広 く, 特に上䫟第 2 乳臼菊間幅径に有意差を認めている. 加藤 $(1979)^{30)}$ は愊径には有意な性差あり, 丸山 (1971) ${ }^{28}$ ' は上.頢前雨列弓幅を除き有意差を認め、安藤（1984） ${ }^{10)}$ は, 下顎第 1 乳画間のみ, 北島 $(1974)^{91}$ は $3 \sim 5$ 歳の全測定部位間に有意差が認められ，男が女より広い とそれぞれ報告している．沖䋥幼児では，上下顎，前後 雨列亏幅のいずれも男児が女坚より有意に広く，諸家の 報告と一致した結果である。

沖縄幼児の柬列弓幅を他の報告と比較すると， 3 歳児 では, 上顎前齿列弓幅は男 $31.50 \mathrm{~mm}$, 女 $30.70 \mathrm{~mm}$ で, 
一色ら $(1970)^{131}$ の男 $30.70 \mathrm{~mm}$, 女 $29.82 \mathrm{~mm}$, 丸山 $(19$ $71)^{28)}$ の男 $30.72 \mathrm{~mm}$, 女 $29.83 \mathrm{~mm}$ ，兼松 $(1973)^{14)}$ の $30.15 \mathrm{~mm}$, 北舄 $(1974)^{9}$ の男 $30.47 \mathrm{~mm}$, 女 $29.80 \mathrm{~mm}$ よりやや広い。上頢後菌列弓幅は男 $47.10 \mathrm{~mm}$, 女 45.20 $\mathrm{mm}$ で，一色ら（1970） ${ }^{13}$ の女 $45.54 \mathrm{~mm}$ と同程度であ るが，小野ら $(1960)^{11}$ の男 $46.48 \mathrm{~mm}$, 女 $44.89 \mathrm{~mm}$, 一色ら $(1970)^{13)}$ の男 $45.88 \mathrm{~mm}$, 兼松 $(1973)^{14)}$ の 45.76 $\mathrm{mm}$ よりやや広い。下䫟前歯列弓幅は男 $24.68 \mathrm{~mm}$ ，女 $24.02 \mathrm{~mm}$ で，小野ら (1960) ${ }^{11}$ の $23.28 \mathrm{~mm}$ ，一色ら (19 $70)^{13)}$ の男 $23.80 \mathrm{~mm}$, 女 $23.28 \mathrm{~mm}$, 丸山 $(1971)^{28)}$ の 男 $24.18 \mathrm{~mm}$, 女 $23.64 \mathrm{~mm}$, 兼松 $(1973)^{14^{\prime}}$ の $23.44 \mathrm{~mm}$, 加藤 $(1979)^{30)}$ の男 $23.67 \mathrm{~mm}$, 女 $22.93 \mathrm{~mm}$, 北島 $(19$ 74) ${ }^{9}$ の男 $24.31 \mathrm{~mm}$, 女 $23.38 \mathrm{~mm}$ よりやや広い。下顎 後㐘列月幅は男 $39.46 \mathrm{~mm}$ ，女 $38.36 \mathrm{~mm}$ で，一色ら 19 70） ${ }^{131}$ の男 $39.60 \mathrm{~mm}$ ，女 $38.67 \mathrm{~mm}$ ，兼松（1973）14'の $38.82 \mathrm{~mm}$ と大差ない. 4 歳児では，上顎前柬列引幅は 男 $31.72 \mathrm{~mm}$ ，女 $30.92 \mathrm{~mm}$ で，兼松（1973）14の30.26 $\mathrm{mm}$, 北島 $(1974)^{9}$ 'の男 $30.64 \mathrm{~mm}$, 女 $30.08 \mathrm{~mm}$ より 広い，上額後䨑列亏幅は男 $47.82 \mathrm{~mm}$, 女 $46.00 \mathrm{~mm}$ で， 小野ら (1960) ${ }^{11}$ の男 $47.50 \mathrm{~mm}$ ，女 $45.49 \mathrm{~mm}$ ，兼松 (19

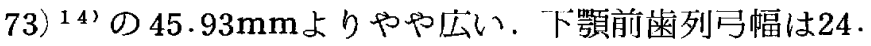
$62 \mathrm{~mm}$, 女 $23.82 \mathrm{~mm}$ で, 小野ら $(1960)^{11}$ の $23.61 \mathrm{~mm}$, 兼公 $(1973)^{14 \prime}$ ( $23.65 \mathrm{~mm}$, 加藤 $(1979)^{301}$ の男 23.98 $\mathrm{mm}$, 女 $23.12 \mathrm{~mm}$, 北島 (1974) ${ }^{91}$ の男 $23.87 \mathrm{~mm}$, 女 $23.40 \mathrm{~mm}$ より広い。不顎後菌列幅は男 $40.21 \mathrm{~mm}$, 女 $38.42 \mathrm{~mm}$ で，兼松 $(1973)^{14 \prime}$ '38.68mmより広い. 5

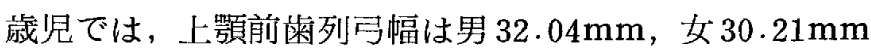
で,兼松 (1973) ${ }^{14)}$ の $30.72 \mathrm{~mm}$, 北島 (1974) 91 の男30.55 $\mathrm{mm}$ ，女 $30.14 \mathrm{~mm}$ より広い，上顎曰歯列弓幅は男 46.76 $\mathrm{mm}$, 女44.82mm で, 小野ら (1960) ${ }^{11}$ の男 $47.72 \mathrm{~mm}$, 女 $46.43 \mathrm{~mm}$ より狭いが, 兼松 $(1973)^{14)}$ の $46.14 \mathrm{~mm}$ と 大差ない．下顎前歯列弓幅は男 $25.00 \mathrm{~mm}$, 女 $23.55 \mathrm{~mm}$ で，小野ら $(1960)^{111}$ の $23.88 \mathrm{~mm}$, 北島 (1974) 9' の男 $24.20 \mathrm{~mm}$, 女 $23.31 \mathrm{~mm}$ より広いが, 加藤 $(1979)^{30}$ の 男 $25.60 \mathrm{~mm}$, 女 $23.81 \mathrm{~mm}$ よりやや狭く，兼松（1973） 14)の $24.21 \mathrm{~mm}$ と大差ない。下顎後歯列弓幅は男 39.22 $\mathrm{mm}$, 女38.66mm で, 兼松 $(1973)^{141}$ の39.45mm より

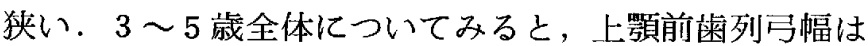
男 $31.78 \mathrm{~mm}$ ，女30.71mmで，小野ら $(1960)^{11)}$ の30.73 $\mathrm{mm}$ より広い，下顎後粜列幅は男 $39.75 \mathrm{~mm}$ ，女 38.46 $\mathrm{mm}$ で, 小野 $(1960)^{111}$ の男 $39.78 \mathrm{~mm}$, 女 $38.62 \mathrm{~mm}$ と 差はない．また，北九州奻児と比較した結果では，女の 下顎後蒾列弓幅を除き, 上下顎, 男女之も沖縄幼児が北 九州幼児より広い傾向にあり（図 8)，門司を調查地区
とした北島 $(1974)^{91}$ を始め，他家の報告值との比較と む同傾向である。

乳歯列引の長径, 幅径の年齿差に関しては古くより多 くの報告があり11-12,14,17,28,30-34)，(1)長径は経年 に伴い減少し, 幅径は增加するというもの11-12,14,28， 31-33)，(2)歯列局の発育を乱す外的因子がない限り幅径 はほとんど増加しないとするもの 17,191 ，(3)蒾列長は 増加と減少の両方が認められるとするもの 别されている。

霜列弓長および幅径の年齢差に関しては, 著者の沖縄 幼归は断面観察であるから, 成長変化としてとらえるの は適当でないが，年齢間で比較すると，長径は高年齢皃 ほど長い傾向がみられ，逆に幅径は，ほとんど差が認め られない，乳蒌列马の長径および幅径の年齢間の比較や 経年観察による成長量の報告は多く見受けられるが，北 九州市門司区幼児を対象とした，教室の北島 $(1974)^{91}$ は,長径は男の $4 \sim 5$ 歳間を除き有意差が認められ， 3 ， 4，5歳の順に長く，幅径は，男の $3 \sim 5$ 歳間の上顎第 1 , 第 2 乳曰蒾間, 下顎第 2 乳曰茵間, $3 \sim 4$ 歳間の上 顎第 2 乳田歯間, 女の $3 \sim 5$ 歳間の上顎第 2 乳臼㐘間に 有意差を認め， $5 ， 4 ， 3$ 歳の順に広がったと報告して いる。

2 歳 6 月から経年調査を行なった小野ら(1960) ${ }^{11)}$ は, 上顎の第 2 乳臼柬間幅はやや増大し，乙れに志して画列 弓長は僅かながら減少しているが，全般的にみて完全乳 曾列には成長による量的変化はないとみて差支えないで あろうと絬論づけている．望月 $(1965)^{12}$ は，3歳6月 から経年調査の結果，全体としては僅かながら増加がみ られたが，個体別にみると，明らかに増加を示すもの と, 全く変化ないものと, 少数ではあるが, 減少するも のとがあり，個体差のある資料を平均したために，増加 量はごく僅かになってしまったとしている．兼松(1973) 14)は，経年による乳雨列引長径の減少と幅径の増加を 認め, 加藤 $(1979)^{301}$ は, 個成長では, 崡列马長は男女 とも 3 歳から増秢に伴い減少が起るが，4歳まで増加し たのち減少する症例もある。幅径は増加する症例と減少 する症例の 2 型がある.上顎より下額が，男より女が早 く成長変化が推移する。以上より，平均成長は個成長の ,$+-の 2$ 型から 4 歳までほとんど変化しないと述べて いる．いずれにせよ，集団としてとらえる場合には，顎 発育状沉や第 1 大曰萪の萌出時期の問題等による個体差 ある個人の分布による多少異なった傾向が生ずるものと 思われる。また逆に言うならば，こういった成長量の面 からも，遺伝等を含めた地域性が伺えるかもしれない。 
著者の沖縄幼児では，幅径に年齢差がないという点に おいては, Lewis $(1936)^{191}$, Baume $(1950)^{17}$ らの報 告と一致しているが，長径が，特に下枵前歯部で増㱓的 に長いという傾向は全く異なる結果である．望月 (1965) 12)は，乳歯列期の長径は負の成長が起てるが，それは， 後方歯間幅の増加とともに，後方の長径が減少するから であり，第 1 大曰菌の萌出現象に伴い近心に力を戈よほ されることによると述へ，それは霊長空腺や成長空隙の 閉鎖や減少から説明されるとしている。しかしながら， 沖綶幼児においては，幅径の増加の発現がみられない， 歯間空隙の発現率が高年齢児ほぞ高い，下顎の前方発育 に対して, mesial step type の増加がなく, vertical type が多い,つまり，後方歯牙の近心移動がみられな いなどの理由から，長くなる結果になったのであろう。 このととは，計測点が異なるため比較できなかったが， 杉本 $(1975)^{34}$ も，女では歯列弓幅の減少と歯列弓長の 增加を認めている。

歯列今指数は，㐘列弓型を科学的に示したもので, 変 異係数が比較的小さいととから, 人類学上重要な意義を 有するとされている．永久歯列に扔ける菌列弓指数は多 くの論文に見受けられるが，乳䨑列に関しては，北島 $(1974)^{91}$, 安藤 $(1984)^{10}$, 丸山 $(1971)^{291}$, 杉本 $(19$ 75) ${ }^{33}$ 'にみられるのみである. 沖縄幼児の歯列局指数は いずれの項目も有意な性差はみられず，男女とも近似し た值であった．乙の結果は，丸山（1971）291 と同傾向を 示したが，歯列弓長幅指数で有意差を認めた北島 (1974) 9)や，上顎前抢よび後歯列弓指数，下顎前後歯列弓幅指 数に有意な性差を認めた安藤 $(1984)^{10}{ }^{10}$ ，また，4 歳の 上顎歯列弓長幅指数, 下䫇前歯列弓打よび歯列弓長幅指 数, 5 歳の下顎前蒾列弓長幅指数に有意差を認めた杉本

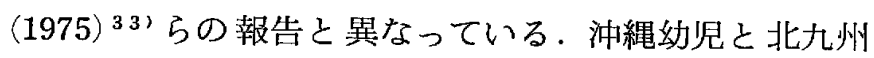
幼児を歯列弓指数を基侤考元ると，男女とも前後歯列可 幅指数は沖縄幼児が有意 $(\mathbf{p}<0.01 ， 0.05)$ 亿大きく， 下顎前後歯列引長指数は, 逆に沖縄が小さい傾向にあ る.これは, 沖縄幼児の乳疄列弓が, 北九州幼児に対し， 上下顎とも幅径においては，前方が広く，後方は同程度 であるととによるし，下顎の長径に関しては前方が短か く，後方が長い傾向によるものと言える．それは同時に 下顎前歯列局指数が沖縄が北九州より有意 $(\mathbf{p}<0.01)$ に小さい結果でもある.

以上, 沖縄幼児の乳柬列弓計測について総括すると， 沖縄幼児は, 乳霜列の幅径に有意差が認められ, 男が女 占り広いが，長径には著差はない，また，幅径に年噛差 は認められない，長径は 5 歳巟が長い傾向にある．北九
州幼児に対し，長径は長く，幅径は，歯列号後部では著 差はないが前部で広い傾向にある．乙の所見は，先に， 沖縄県成人女性の永久歯列弓，口蓋について報告を行な った教室河野 $(1982)^{6}$ 'の，沖縄女は北九州女より歯列 弓長径は短く, 幅径は差がなかったとする報告と異って おり, 沖縄住民の乳歯列期においては, 永久䨑列(成人) の特徵とは，また異なる形質を示すものと考えられる (図 8 ).

\section{結 論}

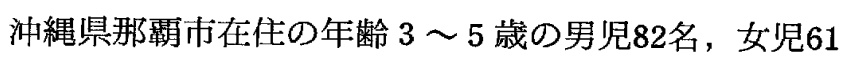
名, 計143名について, 乳雨列可諸形質を明らかにす る目的で, 北九州市在住の同年齢の幼児をコントロール として，石高模型上で観測および計測を行ない，以下の 結論を得た。

1. 乳鋓列咬合状態は, 正常咬合者が男女とも65\%強 であり，高年齢児ほど高率であった，不正咬合の出現頻 度は，過蓋咬合が $11.9 \%$ （男女計）と最も高く, 性別に みると，切端咬合は女児が高く，交叉咬合は男児が高い 傾向であった。

2. 歯間空陌の型別出現頻度は, 上顎では, 男女とも PS +DS が明らかな高率を示したが，下顎では，PS+ DS および閉鎖型が高く，特に，女児の閉鎖型が高率で あった。

3. Terminal plane の型別出現頻度は, VV 型が男 $56.1 \%$ ，女60.6\% と最も高率で，次いで， MM 型， DD 型, VM 型の順で，VD型，MD 型は 0\%であった。

4 . 歯列弓長は, 男女間に性差はなく, 北九州幼児と 比較すると, 男女とも下顎前歯列弓長では短いが, 上顎 前および後歯列弓長, 下顎後歯列弓長では長い傾向にあ った。

5 、歯列弓幅は，男児が女児より有意に広く，北九州 幼児と比較すると, 女児の下筫後霜列弓幅を除き, 男女 各項目とも広い傾向にあった。

6 . 蒾列弓指数は, 男女間に性差はなく, 北九州幼児 と比較すると, 上・下顎前後畗列弓幅指数では, 男女之 も有意に高かったが, 男児の下㖽前後崡列長指数, 下 顎前歯列弓指数では有意に低かった。

稿を終るに臨み，本研究に終始御愁切なる御指導，御 校閲を賜った九州䨑科大学口腔衛生学教室, 故佐伯榮一 教授，並びに竹原直道教授に深甚なる感謝の意を表しま す.また, 日夜をいとわず種々の御教示, 御助言を戴き ました宮崎秀夫助教授に満腔の謝意を表します。あわせ て,種々の御協力を戴きました教室員各位に感謝します. 


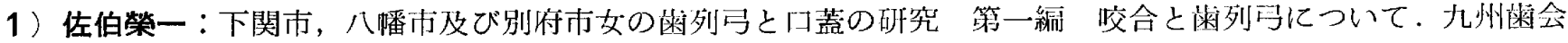
誌 $12: 336-352,1958$.

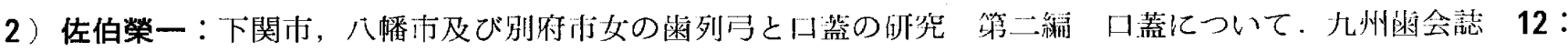
$353-361,1958$.

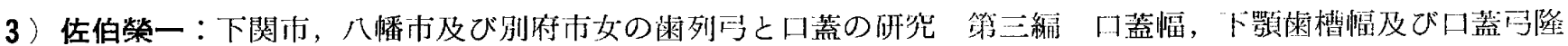
長について，九州柬会誌 $17: 1-10.1963$.

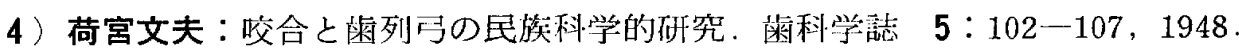

5 ）荷宮文夫・末原靖弘・矢野健一郎・上田茂治：九州成人の柬列马と日盖の大きさ。九州雨会蒜 $22: 119$ $136,1968$.

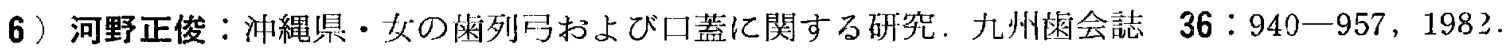

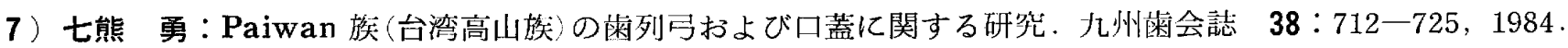

8 ）西岡 信：Rukai 族(台湾高山族)の歯列弓扔よび口蓋に関する研究. 九州霜会誌 38：1003-1017，1984.

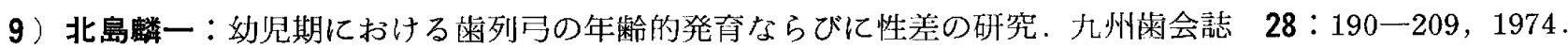

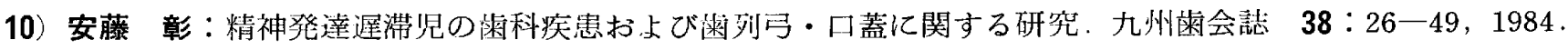

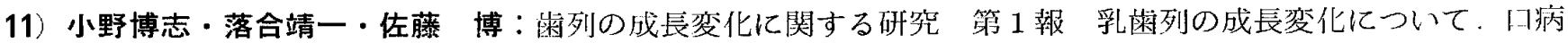
誌 $27: 361-367,1960$.

12）望月清之：夹列の成長変化に関する経年的研究．日病誌 $32: 357-367,1965$.

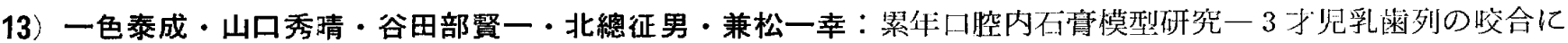
関する諸問題一。菌科学報 $70: 113-129,1970$.

14）兼松一幸：乳歯列今の累年石育模型による形態学的研究．歯科学報 $73: 528-584,1973$.

15）深田英朗：乳霜全びに乳菌列の統計的研究．生物統誌 $1: 1-16,1952$.

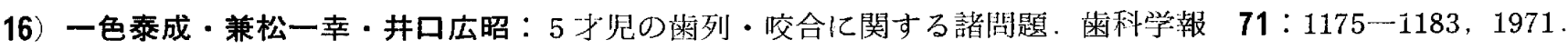

17) Baume, L.J. : Physiological tooth migration and its significance for the development of occlusion. J. Dent. Re.;. $29: 123-132,331-337,338-348,440-447,1950$.

18) Lundström, A. : The significance of early loss of deciduous teeth in the etiology of malocclusion. Amer. J. Orthod. 41:819-826, 1955.

19) Lewis, S.J. : Some aspects of dental arch growth. J. Amer. Dint. Ass. 23:277-294, 1936.

20) Boyko, D.J. : The incidence of primate spaces in fifty 3 -year-old children of the Burlington Study. Amer. J. Orthod. 54:462-465, 1968.

21）江藤一洋：乳歯列において見られる柬間空隙に関する研究．小児歯誌 $7: 191 ， 1969$.

22）小野博志：乳歯列の歯問空隙。歯界展望 $37: 581-587,1971$.

23）丸山 茂：乳雪列弓の形態学的研究 2 . 蒾間空隙の発現状沉. 歯科学報 $71: 176-182,1971$.

24）武田允文：乳歯列における䎃間空隙の研究。小坚蒾誌 $10: 174,1972$.

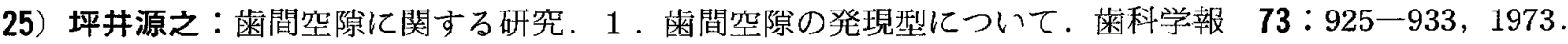

26）岡本全宏：霊長空陌の発育にともなう変化に関する研究。菌科学報 79：2417一-2432, 1979.

27) Cārlsen, D.B. and Meredith, H.V. : Biologic variation in selected relationships of opposing posterior teeth. Angle Orthod. 30:162-173, 1960.

28) Friel, S. : Occlusion. Observations on its development from infancy to old age. Int. J. Ortho. $13: 322-343,1927$.

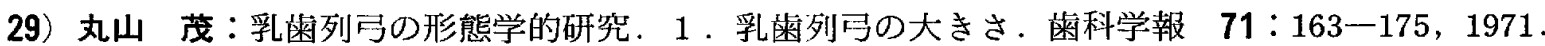

30）加藤敬介：日本人小児期における歯列弓の成長発育に関する研究一 3 才览乳歯列より永久歯列に至る経年石 碎模型汪よる検討一。歯科学報 $79: 991-1027,1979$. 
31) Goldstein, M.S. and Stanton, F.L. : Changes in dimensions and form of the dental arches with age. Int. J. Ortho. $21: 35-380,1935$.

32) Cohen, J.T. : Growth and development of the dental arches in children. J. Amer. Dent. Ass. $27: 1250-1262,1940$.

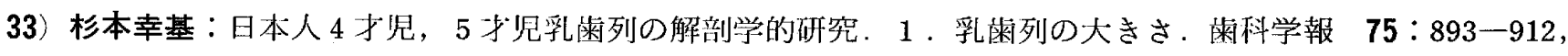
1975.

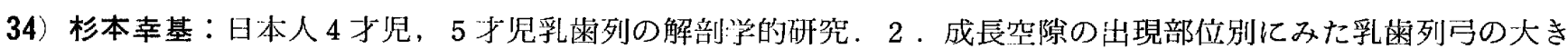
さ. 歯科学報 $76: 797-823,1976$. 